\title{
Mesenchymal Stem Cell Transplantation: New Avenues for Stem Cell Therapies
}

\author{
Pravin D. Potdar* and Sharvari S. Deshpande
}

Department of Molecular Medicine \& Biology, Jaslok Hospital \& Research Centre, Mumbai, India

\begin{abstract}
Stem cells are highly specialized biological cells that have the potential to differentiate and regenerate various cells and tissue types. Stem cell research was first initiated way back in 80 's due to the discovery of pluripotent embryonic stem cells. However, embryonic stem cells utilization spurred controversy which encouraged scientists to find an alternative for the substitution for ESCs. Human Mesenchymal Stem Cell (MSC), a type of an adult stem cell, exhibits many of the properties as that of embryonic stem cells such as pluripotency, immunomodulatory etc. These adult stromal cells are multipotent and non-hematopoietic in nature. MSCs have the potential to differentiate into diverse cell types including osteocytes, osteoblasts, adipocytes, chondrocytes, cardiomyocytes, neural cells and $\beta$-cells of islets. This differentiation property is exploited by many researchers in clinical and therapeutic applications of these cells against wide variety of diseases including osteoarticular diseases, neurodegenerative diseases, auto-immune diseases, cardiovascular diseases and in renal transplantation. Overall, this review summarises an importance of use of human Mesenchymal Stem cells (MSCs) for regenerative therapies for the cure of these major diseases in human.
\end{abstract}

Keywords: MSCs; Cardiomyocytes; Stem cell therapy; Neurological disorders; Diabetes Mellitus; Osteoarthritis

\section{Introduction}

\section{Stem cells}

Russian histologist Alexander Maksimov, while proposing the theory of haematopoiesis, has first suggested the concept of "stem cell" in 1909 [1]. Later in 1961, James Till and Ernest McCulloch have demonstrated the existence of stem cells in mice which are unusual biological cells found in different tissues throughout the body. These cells have two vital properties, one is an ability to self-renew and second one is an ability to differentiate into diverse cell types for an extended period of time [2-4]. Stem cells are usually recognized and designated on the basis of different functions carried out by them such as those cells that have limitless potential are referred to as totipotent stem cells whereas, those cells which have limited potential are called multipotent, pluripotent or bipolar stem cells $[4,5]$. Stem cells are unspecialised cells which have the capability to differentiate into highly specialized cells via the process of differentiation. These unique properties of stem cells play a cardinal role in maintenance of homeostasis in tissue as well as in repair of damaged tissues [6]. Stem cells are divided into 2 major categories i.e. Embryonic Stem Cells (ESCs) and Adult Stem Cells.

Despite many applications of embryonic stem cells in treatment of diseases like Parkinson's disease, myocardial infarction, Diabetic Mellitus, the use of human embryonic stem cells have its own limitations. The major limitation of use of human embryonic stem cells for such studies is the use of 5-7 days old embryos or non-viable embryos for such experimentation which has many ethical and legal constraints [7]. Secondly, stem cells transplanted from a random donor can lead to high immunological reactions which many times are lethal and third limitation is the use of these stem cells can result into formation of tumours in some of the patients [7]. To overcome the above limitations, scientists are trying to switch over to adult stem cells as an alternative. This review will summarise the importance of Mesenchymal Stem Cells derived from various human tissues and cells for the therapies of various disorders.

\section{Adult stem cells}

Adult stem cells are undifferentiated cells and mostly present in various tissues and organs such as bone marrow, dental pulp, brain, liver, lung, heart and pancreas etc. Table 1 [8-42] shows different Types of adult stem cells along with their sources and differentiation status.

However, adult stem cells also have the ability to differentiate into various mature specialized cells of tissues and organs origin. Several studies have shown that adult stem cells play specific role in repair and maintenance of the tissue in which they are present $[43,44]$. Adult stem cells are also referred to as somatic stem cells. Before these adult stem cells attain a completely differentiated state, they develop an intermediate cell type which can be called as a progenitor or precursor cell. These progenitor cells are partially differentiated in adult tissues or organs which then later divide into fully differentiated cell types [45]. Another exclusive feature of adult stem cells is "their plasticity" [46,47] i.e. these stem cells from one adult organ or tissue have the ability to generate differentiated cell type of another organ or tissue.

\section{Mesenchymal Stem Cells (MSCs)}

Most widely studied adult stem cell especially for its clinical applications are Mesenchymal Stem Cells (MSC) derived from various tissues and organs $[16,17,48-50]$. Mesenchymal stem cells are stromal cells which are non-hematopoietic in nature. These stem cells have the ability to differentiate into various mesenchymal tissues which includes tendon, bone, adipose, muscle, cartilage, ligament etc. [48] or into various other cell types such as myocytes, adipocytes, osteoblasts, insulin-producing cells, chondrocytes etc. [16,17,49-51]. Cohnheim, a German pathologist in 1867, first showed the presence of Mesenchymal stem cell in bone marrow which he referred to as non-hematopoietic

*Corresponding author: Pravin D. Potdar Head of Department of Molecular Medicine \& Biology, Jaslok Hospital \& Research Centre, 15 Dr. G. Deshmukh Marg, Mumbai 400026, Maharashtra, India, Tel: 91-22-66573445; Mobile: 91-9820833530; Fax: 91-22-23520508; E-mail: ppotdar@jaslokhospital.net, ppravin012@gmail.com

Received August 12, 2013; Accepted September 02, 2013; Published September 10, 2013

Citation: Potdar PD, Deshpande SS (2013) Mesenchymal Stem Cell Transplantation: New Avenues for Stem Cell Therapies. J Transplant Technol Res 3: 122. doi:10.4172/2161-0991.1000122

Copyright: (c) 2013 Potdar PD, et al. This is an open-access article distributed under the terms of the Creative Commons Attribution License, which permits unrestricted use, distribution, and reproduction in any medium, provided the original author and source are credited. 
Stem Cells $[16,17,48-52]$. On the basis of the above findings, in 1976, Friedenstein along with his co-workers demonstrated that bone marrow consists of certain types of cells which have the capability to differentiate into other MSCs, into fibroblasts, chondrocytes, osteoblasts and adipocytes [16,17,49-51]. Mesenchymal stem cells also have the ability to differentiate into cells which are of ectodermal, endodermal and mesodermal origin [48].

\section{Molecular characterization of Mesenchymal Stem Cells (MSCs)}

Molecular Characterization defines the particular type of cells isolated or identified during cultural studies, whether they are Mesenchymal stem cells or Hematopoietic stem cells. Several studies have already established that CD105, CD13 and CD73 expressing cells are Mesenchymal stem cells [18,50-53] whereas, cells expressing CD34 and CD45 have hematopoietic phenotypes [18,50-53] As mesenchymal stem cell induces differentiation into various cell types such as neurons, chondrocytes, osteoblast, $\beta$ cells of pancreas, cardiomyocytes etc. The identification of these individual cells types is a major task in understanding their specific phenotypes before these cells can be used for stem cell transplantation for various disorders. The various markers which are so far reported are given in Table 2 [16,50-63].

Based on differentiation capability, expanding features in vitro and diverse genetic and protein expression profiles of Mesenchymal Stem Cell (MSCs), these cells can be used in a wide variety of clinical applications. This has lead to an increase in the number of clinical trials worldwide against a wide variety of diseases. The present review mainly focuses on applications of MSCs in various therapies to cure complicated disorders in humans. The clinical trials for some of these diseases are mentioned in details as follows:

\section{Use of mesenchymal stem cells as therapy for various disorders}

Osteo-articular diseases: Multipotent MSCs have resulted in development of various innovative approaches in treatment of commonly occurring osteoarticular diseases such as osteoarthritis, rheumatoid arthritis and cartilage and bone genetic diseases. It has been known that MSCs have the ability to differentiate into various cell types one of which is chondrocytes. Chondrocytes are the highly specialized cells of the cartilage. Chondrocytes perform a variety of functions which include cellular matrix formation and facilitation of exchange of nutrients and fluids [64]. A lot of research work has been carried on on chondrogenic differentiation of Mesenchymal Stem Cells (MSCs) [65-69]. In recent years, tissue engineering has gained attention as a potential technique for the treatment of various diseases including osteoarthritis [70-76]. Gupta et al. have recently used decellularized goat-lung scaffold from cadaver goat-lung tissue, by modifying with chitosan/nanohydroxyapatite composite and shown that the chondrocyte cells which were layered on this scaffold can grow very well without changing their phenotypes. It was further concluded that this decellularized goat-lung scaffold may provide support to enhance osteogenic potential of chondrocytes cells when used as a scaffold for bone tissue engineering [77]. Such types of studies will help us to find out better therapeutic potential in near future to treat osteoarthritis and bone related diseases. Richardson et al. demonstrated the differentiation of Mesenchymal stem cells derived from bone marrow into chondrocytes using scaffolds of Poly-L-Lactic acid [78]. Intervertebral disc degeneration is usually associated with the lower back pain which can be treated using tissue engineering technique. However, the limitation of this technique is the use of both matrix and cells which are appropriate for the targeted tissue. Therefore, there is an urgent need to develop an alternative system to overcome the above limitation. MSCs derived from bone marrow which has the ability to differentiate into chondrocytes were used for the tissue engineering of intervertebral disc degeneration [78]. This differentiation was also shown on the scaffolds of Poly-L-Lactic acid in order to generate bioscaffolds using tissue engineering [78].

Transforming growth factor- $\beta 1$ (TGF- $\beta 1$ ), insulin-like growth factor-1 (IGF-1) or Bone Morphogenetic Proteins (BMPs) [79,80] CDMP-1, TGF- $\beta 3$ [81-83] etc. are some of the mediators which have the ability to induce differentiation of chondrocytes. It has been observed that TGF- $\beta 1$ plays an important role in chondrogenesis. Bai et al. investigated whether CDMP-1, which is a part of TGF- $\beta$ family, will have the ability to promote differentiation of Mesenchymal stem cells into chondrocytes. Histological staining was performed using a dye (toluidine blue) which confirmed the differentiation of MSCs into chondrocytes similar to TGF- $\beta 1$. Combination treatment i.e. use of both TGF- $\beta 1$ and CDMP-1 showed a synergistic effect and thus this approach will be of great help in repairing the affected cartilage [81]

\begin{tabular}{|c|c|c|c|}
\hline Types of Adult stem cells & Source & Differentiation into various cell types & References \\
\hline Adult neuronal cells & Brain & $\begin{array}{l}\text { Astrocytes, Oligodendrocytes, B lymphocytes, myeloid cells, T lymphocytes, } \\
\text { neurospheres, neuroblasts, Myosin, Laminin, neurons, glia, myofibroblasts, }\end{array}$ & {$[8-15]$} \\
\hline $\begin{array}{l}\text { Mesenchymal stem cells } \\
\text { (MSCs) }\end{array}$ & $\begin{array}{l}\text { Adipose tissue, peripheral blood, } \\
\text { wharton's jelly }\end{array}$ & Chondrocytes, osteoblasts, adipocytes, cardiomyocytes, hepatocytes. & [16-28] \\
\hline Haematopoietic stem cells & Bone marrow, peripheral blood & $\begin{array}{l}\text { Dystrophin fibers, vascular cells, hepatocytes, neural cells (microglia and macroglia), } \\
\text { Cardiac cells, skeletal cells, retinal cells, dendritic cells. }\end{array}$ & {$[17,18,29-36]$} \\
\hline Adult olfactory stem cells & Olfactory bulb/mucosa & Neurons, glia, neurospheres, oligodendrocytes & [37-39] \\
\hline Intestinal stem cells & Small intestine/ intestinal crypts & Enterocytes, goblet cells, neuroendocrine cells, and Paneth cells & {$[40,41]$} \\
\hline Mammary stem cells & Mammary glands & Myoepithelial cells, ductal epithelial cells and alveolar epithelial cells & {$[40,42]$} \\
\hline
\end{tabular}

Table 1: Types of Adult Stem Cells.

\begin{tabular}{|l|l|l|}
\hline Types of markers & Markers expressed & References \\
\hline MSCs surface markers & $\begin{array}{l}\text { CD29, CD44, CD90, CD105, STRO-1, VCAM (CD106), ALCAM(CD166), vimentin, and } \alpha \text { smooth muscle actin, CD200, } \\
\text { SSEA4 and CD140a, N-cadherin, CD73, CD13, CD34, CD146, CD54. }\end{array}$ & [50-53] \\
\hline Pluripotency markers & Oct 4, Oct 4A, Nanog, Sox-2, TERT, Stat-3 & [53,54] \\
\hline $\begin{array}{l}\text { Cytokine markers } \\
\text { IL-6, IL-8, IL-11, IL-12, IL-14, IL-15, LIF, G-CSF, GM-CSF, M-SCF, FL and SCF, ENA-78, GRO, IL-13, MCP-1, OSM, IP-10, } \\
\text { MIF, MIP-3a, osteoprotegerin, TIMP-1, TIMP-2, IL-27 and IL-10R, IL-13R and IL-17R }\end{array}$ & [53,57] \\
\hline $\begin{array}{l}\text { Growth factor } \\
\text { receptors }\end{array}$ & $\begin{array}{l}\text { BFGF-R, FGF-4, FGF-7, FGF-9, PARC, PIGF, TGF- } 32, \text { TGF- } 33, \text { (Cord Blood-MSCs),PDGF-AB, IGF-1, VEGF-A and } \\
\text { VEGFR-1 (Adult bone marrow MSCs) }\end{array}$ & [16,57-60] \\
\hline Chemokine receptors & CXCL9, CXCL10, CXCL11, CXCR4, CCR2, CCR5, CX3CR1, CXCR6, CCR1, CCR7, CCR8 and CXCR3 \\
\hline
\end{tabular}

Table 2: Molecular Markers of Mesenchymal Stem Cells. 
Similar study was performed by Danišovič et al. demonstrating in vitro differentiation of bone marrow derived MSCs and adipose tissue derived MSCs into chondrogenic cells with or without TGF- $\beta 1$ [19].

Galectin-9 plays a very important role in stimulating immune responses. It has been observed that galectin- 9 has the ability to repair the damaged cartilage in the arthritis induced rat model. Arikawa et al. tried to examine whether there is any specific role of galectin-9 in differentiation of MSCs into chondrogenic cells. It has also been observed that during induction using TGF- $\beta 3$, MSCs express galectin- 9 indicating that it can be specifically used for the differentiation of MSCs into chondrogenic cells and would be helpful in the repair of damaged cartilage [82]. Maumus has evaluated the role of Adipose Tissue Stem cells (ASC) on chondrocytes from Osteoarthritic (OA) patients to show that ASC can be used for the cure of osteo-articular diseases. They have used primary chondrocytes and ASCs from different sources and bone marrow derived Mesenchymal Stromal Cells (MSC) from $\mathrm{OA}$ donors and co-cultured with chondrocytes in a minimal growth medium. They found that both MSCs and ASCs from different sources allowed chondrocytes in the co cultures to maintain a stable expression of markers specific for a mature chondrocytes phenotype suggesting that ASC can be used for the therapies of osteo-articular diseases [83]. Matsuda et al. isolated MSCs from the bone marrow which was then implanted in a PGLA mesh. These cells were then allowed to grow for 4 weeks in the presence of 2 growth factors -TGF- $\beta 3$, dexamethasone and IGF-1. It was observed that the rate of differentiation of the 3D structure was very high with or without the presence of growth factors [84].

Centeno et al. reported the first clinical trial using autologous bone marrow derived MSCs for the patients with chronic knee pain $[85,86]$. Davatchi et al. performed the human clinical trial for knee osteoarthritis using MSCs. The main aim of this experiment was to study whether MSCs have the potential to reverse the process of osteoarthritis in knee joint. Four osteoarthritis patients were enrolled for this study. Patient's bone marrow MSCs were isolated and injected in one knee of each patient. Three patients showed sign of improvement whereas in case of one the effect was negligible. The results obtained were promising; however, there is a need to improve the efficacy of treatment [87]. Koh et al. demonstrated the effect of MSCs derived from infrapatellar fat on the patients with knee arthritis. Level 3 case studies were performed in which 25 MSCs injections were administered to patients with osteoarthritis. It was observed that Tegner activity scale, mean Lysholm and VAS (Visual Analogue Scale) scores were significantly improved in the patients with knee arthritis. During the follow-up period, no adverse complications were experienced by any of the patients selected for the study. The experimental results were encouraging and indicate that MSCs derived from infrapatellar fat are safe and can be used as an effective therapeutic agent against osteoarthritis [88].The chondrogenic differentiation of MSCs has proved to be a valuable therapeutic tool in treatment of osteo-articular diseases along with its applications in tissue engineering techniques.

\section{Mesenchymal stem cell therapies in neurological diseases}

Several studies have shown that Mesenchymal stem cells isolated from various sources such as adipose tissue, bone Marrow, Cord blood cells etc are very well differentiated into functional neuron cells [8-15]. Neurological disorders are mainly affected due to defect in neuron cells causing major movement disorders and there is no cure for these diseases so far. Therefore it was hypothesised that the functional neurons obtained from differentiation of MSCs can be used for therapies of these disorders. Several scientists have done preliminary work in this area and it was really exciting that there are positive results in curing these defects by using animal's model systems. This part of the review will summarise the research work carried out in regenerative therapies for Parkinson's disease, Huntington's disease, Amyotropic Lateral Sclerosis (ALS) and Stroke by using Mesenchymal stem cell derived from various tissue or blood cells.

Parkinson's disease: Parkinson's Disease (PD) is a neurodegenerative disorder which is caused due to the destruction of neurons found in the substantia nigra region in the brain that is responsible for controlled movement [89]. This affects the level of dopamine (neurotransmitter) resulting in an improper movement [89]. Earlier transplantations were carried out using embryonic mesencephalic tissue. This technique made use of dopamine neurons which were grafted on to the denervated substantia nigra resulting in the release of dopamine. However, there were lot of problems associated with the use of embryonic tissue. To overcome the above limitations, stem cells had been used to generate large number of neurons with certain dopaminergic features. However, their survival rate in various Parkinson's disease models were found to be very poor and whether these cells would function in a similar manner as that of normal dopamine neurons was unclear [90]. This experimental study raised many scientific issues as well as enthusiasm regarding use of stem cells in treatment of Parkinson's disease. Levy et al. demonstrated that adult and embryonic stem cells have the ability to self-renew and differentiate into dopamine neurons [91]. This new technology promises to replace tissue transplantation techniques in Parkinson's disease [91-93].

Fu et al. demonstrated the isolation of Human Mesenchymal Stem Cells from Wharton's jelly found in the umbilical cord. These MSCs were allowed to transform into dopamine neurons by culturing them into a conditioned medium followed by culturing in sonic hedgehog and then in FGF8 which are characterized by using positive staining [20]. The neuronal stem cell transplantation was carried out in the Parkinson's disease induced rats. It was observed that the transplanted stem cells remained viable for at least 4 months indicating that the MSCs isolated from the umbilical cord can be used as a novel therapeutic modality in treatment of Parkinson's disease [20]. Similar study was performed by Weiss et al. using Wharton's jelly of human umbilical cord [21].

$\mathrm{Li}$ et al. demonstrated the use of bone marrow stromal MSCs in treatment of Parkinson's disease. In this experiment, adult mouse was injected with MPTP (1-methyl-4-phenyl-1, 2, 3, 6-tetrahydropyridine), a neurotoxin which was used to induce Parkinson's disease in the mouse. Transplantation of bone marrow stromal MSCs which were cultured and tagged with bromodeoxyuridine was performed in the intra-striatal region after one week of MPTP treatment. It was observed that MSCs transplanted mice showed great progress in rotarod test on $35^{\text {th }}$ day as compared to the controls. Immunohistochemical analysis showed the presence of viable bromodeoxyuridine- labelled MSCs in the intra-striatal region for 4 weeks after treatment. These results correlate with the above findings indicating that stem cell transplantations will be of great help in treatment of Parkinson's and other neurodegenerative disorders [94]. Chao et al. demonstrated that MSCs transplantation in the MPTP treated mice results in dramatic decrease the toxicity of MPTP mainly because of released TGF- $\beta$ in the substatia nigra region and not due to differentiation of MSCs into dopamine neurons [95]. These results show that transplantation of MSCs can reduce the cytotoxicity of MPTP [95].

Offen et al. and Blondheim et al. showed the transplantation of differentiated and undifferentiated MSCs in the intra-striatal region into the animal model induced with 6-hydroxydopamine resulting in 
an increase in the level of tyrosine hydroxylase in the striatal region thus improving motor behaviour in a mouse model of Parkinson's disease [96,97]. Park et al. tried to examine the use of MG-132 (proteasome inhibitor) in order to understand whether mesenchymal stem cells have any protective function against the degeneration of dopamine neurons in vivo and in vitro. It was observed that treating the neurons with MSCs using MG-132 resulted in decrease in the destruction of neurons in vitro [98]. Similar treatment of MG-132 along with MSCs given to the rats showed increased survival rate of tyrosine hydroxylase expressing cells by $50 \%$ indicating that MG-132 along with MSCs can be used as a novel therapeutic tool in treatment of Parkinson's disease [98]. Similar study was carried out to check whether any anti-inflammatory process have the ability to induce protective function against the loss of dopamine neurons in vivo and in vitro [99-101]. Kim et al. have used LPS (Lipopolysaccharide) to generate inflammation-induced models both in vivo and in vitro in order to investigate whether MSCs possess any neuroprotective function on the dopamine neurons via any anti-inflammatory process. It was observed that LPS induced TNF- $\alpha$, activation of microglia, expression of nitric oxide synthase. In co-cultures of neurons and microglia, MSCs reduced the loss of tyrosine hydroxylase positive cells. In vivo studies showed similar results indicating that MSCs have the ability to produce neuro-protective function in the presence of anti-inflammatory process [102]. Schwarz et al. have genetically engineered bone marrow stromal MSCs in order to examine its effect on the Parkinson's disease induced rat model. Both rat and human bone marrow stem cells were genetically modified using retroviruses that have the ability to encode 2 enzymes: GTP cyclohydrolase I and tyrosine hydroxylase. The genetically modified cells also produced L-DOPA which gained multifunctionality on transduction using retroviruses in vitro. To check the viability of the MSCs in vivo, genetically modified rat MSCs were incorporated into the Parkinson's disease induced rat model. It was observed that the injected MSCs survived for 87 days indicating that genetically modified MSCs can be effectively used in the treatment of Parkinsonism [103]. Similar study was performed by Lu et al. using adeno-virus as a vehicle in order to transfect tyrosine hydroxylase gene to the bone marrow MSCs. Immunohistochemical analysis and HPLC (High Performance Liquid Chromatography) was performed to check the levels of dopamine. The efficacy of genetic expression was found to be $75 \%$ which correlate with the above findings [104]. Another study was performed to induce expression of neutrophin, neutrophin- 3 trkC receptors of high affinity and nerve growth factor using adult MSCs in order to develop stem cell therapy against Parkinson's and other neurological disorders. The production of neutrophins was found to develop neuro-protective mechanism against destruction of neurons [105]. It has been observed that umbilical cord MSCs have wide range of applications especially in the treatment of Parkinson's disease. Xiong et al. demonstrated the combined expression of both human MSCs and VEGF as it has been observed that both have good neuroprotective ability. Similar protocol was followed as that of $\mathrm{Lu}$ et al. which involved use of an adeno-virus [106]. This VEGF gene transfer was performed in hemi-parkinson's rats. It was observed that human MSCs were transformed into dopamine neurons based on different markers expression. VEGF was found to increase the level of dopamine neuronal differentiation also reducing the loss of dopamine neurons during the differentiation of human MSCs. This work indicates that human MSCs can be used as a vehicle in gene therapy in treatment of Parkinson's disease [107]. Recent study was performed using transplantation of autologous A9 dopamine neuronal cells in hemiparkinson's disease induced macaques. It was observed that there was some improvement in the behaviour of motors. Positron Emission Tomography (PET) was performed using $\left[{ }^{11} \mathrm{C}\right]$-CFT in order to examine the increase in the expression of dopamine transporter. This data reveals that the autologous dopamine neuron therapy is safe and efficient in the treatment of Parkinson's disease [108].

After working tremendously on MSCs transplantation in animal models, Venkataramana et al. performed an open-labelled analysis of transplantation of bone marrow MSCs in Parkinson's disease. Seven patients suffering from Parkinson's disease (age varying from $22-62$ years) were signed up for this pilot scale study. Single dose of bone marrow MSCs were injected into the patients in the sub-lateral ventricular region. These patients were examined for a period of 1036 months. It was observed that 3 out of 7 patients showed proper improvement which was measured using UPDRS (Unified Parkinson's Disease Rating Scale). These results indicate that this process is safe and efficient without any severe side-effects and can be effectively used in the treatment of Parkinson's disease [109]. On the basis of above findings, another study was performed by Venkataramana et al. at pilot scale using allogenic human bone marrow derived MSCs. It was reported that some patients in the early stage of Parkinson's disease showed more improvement as compared to the patients who were at the later stage of the disease. These results demonstrated that allogenic bone marrow derived MSCs are effective in patients which are in the early stage of Parkinson's disease [110]. Thus over all it is suggested that the differentiation potential of MSCs into dopamine secretory cells have enhanced its use in clinical trials globally against Parkinson's disease thereby giving hopes to Parkinson's disease patients.

Huntington's disease: Huntington's disease (HD) is a fatal autosomal dominant neurodegenerative disorder which usually occurs due to the defective gene located on short arm of chromosome 4 [111] Huntington's Disease Collaborative Research Group (HDCRG) in 1993, are the first to report the isolation of abnormal gene which contains expanded CAG trinucleotide repeat sequence which are responsible for coding Huntingtin Protein (HTT) [111,]. The mutations in the HTT gene result in loss of neuronal functions especially in the cerebral cortex and striatum region [112-114]. There is no specific treatment or therapy against Huntington's disease. However, efforts have been made to reduce the symptoms and other related complications which can provide temporary relief to the patients. Thus novel stem cell therapies against Huntington's disease have gained major attention in recent years to treat or cure this disease.

Various studies have been performed using animal models for Huntington's disease using different analogs of glutamic acid like kainic acid [115], ibotenic acid [116] and quinolinic acid [117-119]. Recently efficiency of MSCs transplantation was tested by Rossignol et al. has studied use of MSCs stem cell in the Huntington's disease induced rat model using 3-nitropropionic acid. This study has shown that none of the transplanted MSCs were differentiated into neural phenotypes in rat. However, it was clearly observed the change in the behaviour of 3-NP treated HD rats without any neuronal replacement [120]. Jiang et al. introduced bone marrow derived MSCs in QA (quinolinic acid) rat model. It was observed that MSCs were able to survive and differentiate into neurons in the affected striatal region of this rat and also reduced motor malfunctioning and degeneration of striatum in these QA rats. The said experiment have also shown that certain neurotrophic factors such as brain-derived neurotrophic factor (BDNF), ciliary neurotrophic factor (CNTF) and nerve growth factor (NGF) were over expressed by these transplanted MSCs [121]. Sadan et al. have shown that MSCs not only have the ability to secrete neurotrophic factors but can also express astrocytic markers in vitro. It was also observed that MSCs can survive and migrate in the striatal region of the QA induced model [122]. They also demonstrated that 
MSCs possess neuroprotective function in vivo in QA induced mouse model. They found that MSCs derived from Huntington's disease patients can also be induced to secrete neurotrophic factors which showed similar effects to the neurotrophic factor positive cells obtained from healthy individuals [123]. Additionally, Sadan along with his co-workers tried to explore the timing of transplantation of human $\mathrm{NTF}+$ cells into the striatal region of R6/2 transgenic Huntington's disease mouse model and to check whether it can induce survival and functional motor recovery. It was observed that early transplantation did not show any improvement. However, late transplantation showed temporary improvement in its survival and motor neuron function. These results indicate that neurotrophic factor positive cell-based treatment can be used as a novel therapeutic modality in management of Huntington's disease [124].

Bantubungi et al. demonstrated the transplantation of neural stem cells derived from MSCs into the Huntington's disease induced rat model. It was observed that Stem Cell Factor (SCF) expression was highly up-regulated in the affected striatal region. This activation resulted in movement and division of neural stem cells in vitro. This proves that SCF plays a very important role in stem cell transplantation in the Huntington's disease induced rat model [125]. Similar study was performed using genetically engineered bone marrow MSCs in order to understand its therapeutic response on the affected motor neurons in YAC 128 transgenic mouse model for Huntington's disease. It was observed that transplantation in the intra-striatum region resulted in over-expression of brain derived neurotrophic factor. This reduced the degeneration of neurons in the YAC 128 mouse model for Huntington's disease [126]. Another study involving use of genetically engineered MSCs was performed by Scott D. Olson along with his coworkers. Genetically engineered MSCs were found to over-express 2 growth factors: glial derived neurotrophic factor and brain derived neurotrophic factor which are essential for proper functioning of neurons. It was observed that these genetically engineered MSCs have the ability to directly deliver various cytokines into the surrounding environment and also promote proper growth and function of neurons, reduce apoptosis and enhance strong synaptic association between the affected neurons [127]. Lee et al. suggested from his findings that neural stem cells when injected intravenously can provide long term recovery of the striatal lesions in the Huntington's disease induced rat model [128]. From the above findings, MSCs have proved to be a promising tool in treatment of Huntington's disease giving hopes to millions of patients suffering from this fatal disease.

Amyotrophic Lateral Sclerosis (ALS): Amyotrophic Lateral Sclerosis (ALS) is a lethal neurodegenerative disease which causes voluntary muscle paralysis, atrophy and sometimes respiratory problems in patients. In ALS, there is selective destruction of motor neurons in brain and spinal cord. This disorder is also termed as "motor neuron disease" and "Lou Gehrig's disease" [129,130]. Mutations in 5 Mendelian genes have been reported so far which are responsible for causing ALS [131]. Two therapies have been so far prescribed for the treatment of ALS which includes i) direct delivery of therapeutic agents to motor neurons. ii) Development of certain strategies in order to inactivate the defective mutant alleles [132]. However, both these therapies are challenging and not much work has been carried out in this area. The recent breakthroughs in the area of stem cell research in treatment of Parkinson's disease and Huntington's disease have enhanced the possibilities for MSCs derived neural stem cell transplantation in patients suffering from ALS. Recently Mazzini et al. demonstrated the autologous MSCs transplantation in the intra-spinal cord region in ALS patients and none of these patients have shown adverse side-effects of this treatment indicating that this approach may be useful for treatment of ALS patients [131-134]. There after similar study was performed using autologous MSCs in order to study its efficacy and also to evaluate the immunomodulatory effects on MSCs administration in ALS patients. On MSCs transplantation, there was enhanced expression of CD4+CD25+ $\mathrm{T}$ cells along with $\mathrm{CD} 38+$, CD40+, CD83+ and HLA-DR on dendritic cells of myeloid origin. These results indicate that MSCs transplantation is a safe and efficient technique for ALS patients [135].

SOD1 (superoxide dismutase 1) plays an important role as it accounts for 0.1 to $0.2 \%$ of the total cellular proteins in central nervous system. It has been reported that SOD1 mutations are most common in familial ALS [136]. Vercelli et al. transplanted human bone marrow MSCs into the spinal cord of SOD1G93A mice ALS model. It was observed that human MSCs have the ability to migrate and survive in the spinal cord for a longer period of time. It also hinders with the activation of microglial and astrogliosis which was found to obstruct the decrease in the number of motor neurons in ALS mouse model making MSCs a good candidate for treatment of ALS [137]. Different doses of human MSCs obtained from ALS patients were administered in SOD1 mice intrathecally. It was observed that most of the human MSCs effectively migrated into spinal cord and brain making them a promising therapeutic tool for ALS patients [138]. It has been shown that neuroprotective effects of MSCs are widely exhibited into the central nervous system.

Boucherie et al. incorporated human MSCs in the cerebrospinal fluid (CSF) of SOD1G93A rat ALS model. It was observed that MSCs survived, migrated and differentiated into astrocytes in the region where there was degeneration of neurons. Neuroprotective effects were observed by analysing the level of inflammation along with the decrease in the proliferation rate of microglial cells and downregulation of NOX-2 and COX-2 genes [139,140]. These results exhibit neuroprotective function of astrocytes derived from MSCs when injected into the Central Nervous System (CNS) thereby making them an ideal candidate for targeting inflammation in ALS. Further study was carried out to understand the impaired neuroprotective effects of MSCs obtained from ALS rat model in vitro. It was observed that MSCs exhibit high transcription rate, aspartate intake, GLT-1 expression and Glial Derived Neurotropic Factor (GDNF) up-regulation indicating that neuroprotective properties of MSCs can be used as an important tool for the treatment of ALS $[139,140]$. Another study was performed by Nicaise et al. in order to determine the expression of 7 trophic growth factors derived from MSCs and neural stem cells triggered by the proteins extracted from CNS obtained from ALS rat model. The expression profiling of these 7 growth factors were carried out using quantitative PCR. Different expression profiles were obtained. It was observed that brain derived neurotropic factor and nerve growth factor were over-expressed in MSCs as well as neural stem cells when triggered using CNS protein extracts. FGF (Fibroblast Growth Factor) -2, Glial Derived Neurotropic Factor (GDNF) and insulin like growth factor were up-regulated only in neural stem cells and down-regulated in MSCs. Expression of VEGF-A was observed only in MSCs. This data suggest that MSCs and neural stem cells possess different expression profiles and also provides a better understanding of the effect of MSCs transplantation therapy against ALS in patients[140].

In the past few years, most of the MSCs research work has been carried out on ALS using animal models. Recent studies have shown that many clinical trials have been performed using fetal neural stem cells [141-143]. However, as stem cells derived from embryo have its own limitations, there is an urgent need to develop therapies and 
initiate clinical trials against ALS using human MSCs. Success of human clinical trials using MSCs in treatment of ALS will represent a promising platform for effective stem cell based therapies against other neurological disorders.

Stroke: Stroke is a complex cerebrovascular disease, a condition in which the blood supply to the brain is affected. It is caused due to impaired blood vessels that are responsible for supplying blood and other nutrients to the brain. This results in permanent loss of brain function. Various therapies and treatment modalities have been used in order to overcome the problems associated with stroke. MSCs transplantation serves as a valuable tool for stroke patients. Bang et al. and Lee et al. demonstrated the autologous stem cell delivery in ischemic stroke patients. The results showed improved recovery in ischemic stroke patients indicating successful transfusion of autologous MSCs in stroke patients $[144,145]$. Neuroprotective effects of MSCs have been extensively studied in stroke induced models [146-156]. Dharmasaroja et al. suggested that MSCs derived from bone marrow migrate to different parts of brain where they differentiate into neuronal cells and glial cells. Stroke was treated in murine models using both human and non-human MSCs which induced factors like neuroprotection, neurogenesis [152-155], angiogenesis and apoptosis [156]. The results were promising however, certain important properties of MSCs along with their toxicities need to be analysed in order to utilize MSCs as a treatment modality [156]. Yoo et al. demonstrated the transplantation of bone marrow MSCs in the brain of stroke induced rat model. MSCs were found to increase the proliferation and survival rate of the neural stem cells and the newly born neural cells making them a valuable therapeutic tool for clinical practice [157].

One of the important characteristic of MSCs transplantation is their migration efficiency towards the specific target. However, there is an urgent need to standardize therapy protocols in order to enhance their homing ability towards the affected sites in the brain [158-160]. Recently Tsai et al. demonstrated an enhanced effect of valproate and lithium on the migration efficiency of MSCs. It was observed that there was rapid increase in the expression of CXCR4 and MMP-9 which elevated the efficiency of migration of MSCs [161]. Another study was performed by Tsai et al. on the basis of above findings in order to investigate whether the homing ability of MSCs can be enhanced using valproate and lithium so as to augment the recovery in stroke induced rat model after MSCs transplantation. The results obtained were promising making MSCs based therapies a beneficial therapeutic tool for treatment of patients suffering from stroke [162]. To determine the fate of MSCs in middle cerebral artery occlusion (MCAO) rat model after transplantation, MRI technique was used by Daehong et al. MSCs were tagged with ferumoxides which can be observed using MRI after transplantation. High migration efficiency of MSCs was observed which can be of great importance in developing certain effective transplantation approaches against stroke [163]. Similar study was performed to trace MSCs in stroke induced rat model using MRI techniques. Effectene was used as a labelling agent which was transfected to a contrasting agent Gd-DTPA. The efficiency of transfection was found to be $90 \%$ whereas double immunofluorescence analysis showed the differentiation status of MSCs into neurons, glial cells and endothelial cells. The data reveals that this technique can be very useful in tracking down MSCs in stroke induced rat model [164].

Another study was performed using MCAO rat models. Cultured rat MSCs were injected which increased the chances of functional recovery in ischemic stroke induced rat model [165]. Stroke can affect the vital parts of the brain leading to death of an individual. It has been observed that MSCs can prevent brain injuries by stimulating certain growth factors which will induce repair mechanisms [166] On the basis of above findings, Velthoven et al. investigated whether MSCs transplantation can induce functional recovery and secretion of certain growth factors to prevent stroke in neonates. It was observed that injecting MSCs intranasally gave promising results in treatment of stroke affected neonates and found that MSCs over-expressing brain derived neurotrophic factor were also responsible for reduction of brain injury [167]. The different therapeutic properties of MSCs like neuroprotection, angiogenesis, apoptosis and angiogenesis has greatly promoted its role as a cell-dependent therapeutic agent in treatment of stroke.

Professor Keith Muir from University of Glasgow conducted the first clinical trial named "PISCES" trial (phase I clinical trial) using neural stem cells in order to cure stroke patients. This trial was performed to test the safety, efficacy and tolerance level of this experimental therapy in stroke patients. It was observed that PISCES trial gave promising results in large group of stroke patients. The above findings suggest that nine patients showed steady improvement in symptoms related to stroke with zero side-effects showing that this stem cell therapy is very much effective in stroke patients [168]. This human clinical trial would be of great help in encouraging millions of stroke patients to take up stem cell based therapies as an alternative to surgical modality.

\section{Auto-Immune Diseases}

Auto-immune disease is a condition in which the immune system of the patient develops antibodies against its own healthy cells and tissues which are normally present in the body. Most of the autoimmune diseases are difficult to treat and manage. In recent years, Mesenchymal Stem Cell (MSC) therapy has shown promising results in animal models with different autoimmune diseases. MSCs possess a valuable property to modulate the patient's immune system in order to reduce the pathological complications thereby providing permanent relief to the patients [22-28,169-215]. These evidences have encouraged many researchers to conduct clinical trials against various autoimmune diseases. Some of the common auto-immune diseases which have been cured using MSCs are as follows:

\section{Type 1 Diabetes Mellitus}

Type 1 diabetes mellitus also known as hyperglycemia or juvenileonset diabetes usually occur in younger individuals. It occurs due to high level of glucose in blood resulting in major health complications such as stroke, renal failure, blindness, cardiac-vascular diseases and ketoacidosis. It is caused due to insufficient production of insulin. Type 1 diabetes mellitus is also an autoimmune disorder which is caused by the autoimmune action of $\mathrm{T}$ cells on the $\beta$ cells of pancreas [169]. The causal therapy for type 1 diabetes mellitus involves replacement of abnormal $\beta$ cells of pancreas which can be done by organ transplantation. However, the limitation of this therapy is scarcity of donor organs. To overcome this limitation, scientists are switching over to MSCs transplantation as an alternative [170,171]. MSCs transplantation encouraged researchers to explore its differentiation status into $\beta$ cells of islets of pancreas in vitro and to check whether they possess any therapeutic property in treatment of diabetes. Chen et al. demonstrated the differentiation of rat MSCs into $\beta$ cells of pancreas. It was observed that these cells had the ability to control blood glucose level in rats suffering from diabetes indicating that MSCs can be used as a valuable therapeutic tool in treatment of both type 1 and 2 diabetes mellitus [172]. Another study was performed on human MSCs isolated from Wharton's jelly of human umbilical cord by Chao et al. MSCs were induced to differentiate into islet cells. These cells were then injected into the liver of rats suffering from diabetes which was induced 
using streptozotocin. It was observed that islet cells produced C-peptide and secreted human insulin in order to control blood glucose levels. This data suggest that human umbilical cord derived MSCs is an ideal candidate for the treatment of type 1 diabetes [173]. Similar study was performed using both bone marrow MSCs and allogeneic or syngeneic MSCs. It was observed that MSCs effectively destroyed autoimmune T lymphocytes which caused the destruction of $\beta$ cells of pancreas. MSCs also prevented the immune response generated by $\mathrm{T}$ cells against the newly-generated $\beta$ cells of pancreas [174]. Yu et al. isolated MSCs from the bone marrow of diabetic patients and allowed it to differentiate into $\beta$ cells producing insulin in vitro indicating bone marrow derived MSCs are the best source of insulin-producing $\beta$ cells and can be used as a treatment modality against diabetes mellitus [175]. Ramiya et al. demonstrated the reversal study where islet cells producing insulin were generated from the stem cells isolated from pancreas. This study showed the abundant production of $\beta$ cells producing insulin which will be helpful in treatment of diabetes type 1 [176]. Xu et al. infected murine MSCs derived from bone marrow with genetically engineered retrovirus which is carrying insulin gene of human origin. These MSCs were then transplanted intra-hepatically into diabetes-induced mice which gave promising results [177]. Similar study is being performed by other researchers using genetically engineered herpes 1 virus as a therapeutic vector for carrying insulin gene [178]. Ezquer along with his co-workers demonstrated that administration of MSCs in diabetic mice model can result in successful regeneration of islet cells and prevention of kidney damage thereby making MSCs a potent therapeutic strategy against diabetes [179]. Trivedi et al. reported that the combination therapy using adipose tissue derived MSCs along with hematopoietic stem cells are effective and safe in treatment of type 1diabetes [180].

Therapeutic applications of MSCs in treatment of diabetes mellitus type 2 have successfully replaced the use of healthy pancreatic islets from the cadaver donors. However, it is important to encourage the use of MSCs as a therapeutic modality against diabetes mellitus type 2 at the clinical stage by conducting human trials for the same.

\section{Multiple Sclerosis}

Multiple Sclerosis is an auto-immune disease of the central nervous system which is most commonly found early in adulthood. Degeneration of axons and demyelination are important features of this disease [181]. In most of the cases, this disease progresses steadily causing disability ultimately leading to death. Conventional therapies involve use of immunosuppressants which has been observed to be highly toxic and possess severe side-effects [181]. Therefore, there is an urgent need to develop an alternative therapy in treatment against multiple sclerosis. Mesenchymal Stem Cells (MSCs) are specialized cells which have the ability to differentiate into neurons and glial cells. This property makes them an ideal tool in treatment of various neurological diseases including multiple sclerosis. Karussis et al. demonstrated that bone marrow derived MSCs, in the presence of two growth factorsFibroblast Growth Factor (FGF) and Brain-Derived Neurotrophic Factor (BDNF), have the ability to differentiate into neuronal or glial cells most of which were found to express astrocyte surface markers [182]. It was also observed that bone marrow derived MSCs effectively suppressed chronic Experimental Autoimmune Encephalomyelitis (EAE) by inducing neuroprotection in mice. Histopathological analysis showed efficient migration and differentiation of MSCs into neuronal or glial cells in the affected region. These results indicated that MSCs derived from bone marrow can be used in treatment of various neurological diseases including multiple sclerosis [182]. Similar study was performed by Bai et al. using human bone marrow derived MSCs in the presence of hepatocyte growth factor. These MSCs when injected in EAE mouse models, promoted improved recovery in mouse models. It was also observed that these MSCs have the ability to accumulate, reduce the damage and increase the number of oligodendrocytes cells in the affected areas in the central nervous system. These results suggest that human bone marrow derived MSCs can be used as a viable therapeutic tool in treatment of multiple sclerosis [183,184]. Kassis et al. tried to investigate the therapeutic applications of MSCs in EAE induced mice models. It was observed that when injected intravenously, MSCs induced neuroprotective and immunomodulatory effects in the affected region along with characteristic remyelination and regeneration of neurons in some EAE mice models [185]. From the above experimental data, it has been observed that MSCs have the ability to reduce demyelination, axonal degeneration and immune infiltration. It is also found to increases the accumulation and proliferation of neuronal lineage cells in the affected areas in the central nervous system. These small scale experimental studies using animal models have suggested that MSCs are safe and has encouraged many scientists to go ahead with the human clinical trials for the treatment of multiple sclerosis [186-189].

A lot of research work has been carried out using adipose tissue derived MSCs in recent years demonstrating multiple lineage plasticity both in vivo and in vitro [22-28]. It has been observed that adipose derived MSCs possess a property of neuronal transdifferentiation in vitro which in turn may be useful in neuroregeneration in several neurological disorders [25,26]. Constantin et al. demonstrated the intravenous transplantation of adipose derived MSCs in EAE mice model. It was observed that MSCs reduced some symptoms of EAE by stimulating immunomodulatory functions and decreased demyelination and inflammation of the spinal cord. The accumulation of MSCs resulted in increased population of oligodendrocytes in the demyelinated area. The above experimental data shows that adipose derived MSCs possess dual mode of action that is, first it has the ability to suppress the autoimmune action in the early onset of the disease and second it also has the capability to induce regeneration of neurons in the affected area. Therefore, adipose derived MSCs can be used as a valuable therapeutic tool in treatment of multiple sclerosis [27]. Another study involving use of adipose derived MSCs was performed by Hedayatpour et al. In this experiment, remyelination potential of adipose derived MSCs and its effect on the neural cell population already found in the corpus callosum in the cuprizone induced multiple sclerosis mice model was evaluated. It was observed that transplanted adipose derived MSCs survived and showed homing ability in vivo indicating that adipose derived MSCs can be used as an important therapeutic agent in treatment of multiple sclerosis [28].

Bonab et al. estimated the clinical applications of MSCs in order to reduce the complications found in patients suffering from multiple sclerosis. A pilot scale study was performed with ten patients suffering from multiple sclerosis. The status of disability was calculated using Expanded Disability Status Scale (EDSS) which was found to be 3.56. Cultured MSCs were intrathecally injected to these patients [190]. Neurological assessment was performed monthly. It was observed that during the follow-up of 13-26 months, the EDSS of one multiple sclerosis patient showed 5-2.5 score indicating improvement whereas some showed no improvement in EDSS. During the assessment of the functional system, it was observed that there was some improvement in the functions of central nervous system. This study shows that MSCs can be used as a promising treatment modality against multiple sclerosis [190]. Based on the above reference, several other investigators performed pilot scale study using autologous bone marrow MSCs in order to explore the efficacy and safety of cultured autologous 
human bone marrow derived MSCs transplantation in patients suffering from multiple sclerosis. The experimental studies gave positive outcomes thereby making MSCs an ideal therapeutic agent in treatment of multiple sclerosis [135,191]. Barhum et al. demonstrated the differentiation of MSCs into cells producing neurotrophic factors which in turn can be injected intracerebroventricularly in EAE induced mice. It was observed that MSCs exhibited a positive response against EAE in mice resulting in delayed symptoms and high survival rate. These results indicate that the delayed symptoms were mainly due to neuroprotective and immunomodulatory ability of MSCs [192]. On the basis of the above experimental data, Connick et al. and Mehandru et al. investigated the efficacy and safety of MSCs as a neuroprotective agent in treatment of multiple sclerosis. The experimental reports suggest that MSCs can be used as a potent neuroprotective agent and can be safely administered to patients with multiple sclerosis. It has also been observed that MSCs possess reparative and anti-inflammatory activities thereby making them an ideal therapeutic tool which will be feasible and safe for multiple sclerosis patients [193,194].

\section{Systemic Lupus Erythematosus (SLE)}

Systemic Lupus Erythematosus (SLE) is a chronic autoimmune disease which may occur due to genetic, environmental, hormonal and immunological or may be due to certain unknown causative factors. This disease is more frequent in young females and can affect any part of the body. This is characterised by the secretion of autoantibodies against several components of nucleus present in the cell $[195,196]$. It has been observed that at the most four susceptible alleles are required for the progressive development of this disease [196,197]. Out of the four susceptible alleles, genes of Major Histocompatibility Complex (MHC) possess significant contribution to systemic lupus erythematosus [198]. As this disease involves various symptoms and affected organs, severity in each individual's case would be different. This disease is incurable and currently the area of research in order to provide patient an extended and increased quality of life [199]. Traggiai et al. demonstrated the effect of bone marrow derived MSCs on the B cell population in both normal donors and in patients suffering from SLE. It was observed MSCs successfully differentiated and proliferated into $B$ cells (both transitional and naïve). This event was in turn stimulated with the help of an agonist of toll receptor 9 which occurred not in the presence of $B$ cell receptor. Similar event also triggered the polyclonal expansion of B cells obtained from pediatric patients suffering from SLE. This study indicates that bone marrow derived MSCs can be used as a valuable therapeutic tool in treatment of SLE [200]. Schena et al. tried to analyse the effect of murine bone marrow derived MSCs on B cell activation in the F1 mice model for SLE. It has been observed that MSCs have the ability to inhibit differentiation and proliferation of $\mathrm{B}$ cells which are antigen-dependent in vitro. The inhibitory response was due to interferon- $\gamma$ and cell-to-cell contact. MSCs did not affect the secretion of auto-antibodies in vivo. However, it was observed that there was some amount of improvement in the renal function indicating that MSCs may possess a potential role in treatment of renal damage [201]. Sun et al. showed that allogenic bone marrow derived MSCs have the ability to reconstruct the osteoblastic niche in the bone marrow and can reverse the multi-organ malfunctioning as compared to the effect of the immunosuppressive drug cyclophosphamide. The reconstruction of osteoblastic niche resulted in recovery of T cells and homeostasis of the immune system in mice. These promising results in mice encouraged the researchers to use allogenic MSC therapy in SLE patients. It was observed that the patients showed steady improvement in kidney function and in serological markers. These evidences clearly suggest that allogenic bone marrow derived MSCs can be used as a treatment modality against SLE [202]. Several studies were performed using MSCs in order to evaluate the efficacy and safety of its transplantation in SLE patients, most of which gave positive outcomes without any severe complications [203-205]. Choi et al. tried to investigate the efficiency of transplantation and optimum transplantation window for adipose tissue derived MSCs in SLE patients before or after the onset of this disease [206]. In this experiment, F1 mice SLE model were injected with human adipose tissue derived MSCs whereas another experiment was performed by serially transplanting MSCs. It was observed that serial MSCs transplantations before the onset gave more promising results without any side-effects [206]. MSCs transplantation has been widely used in treatment of SLE in animal models both in vivo and in vitro. The promising results of these animal experimentation studies have encouraged many researchers to go ahead with the human clinical trials thereby giving hopes to millions of patients suffering from SLE [207-209].

\section{Crohn's disease}

Crohn's disease is a chronic illness in which severe inflammation occurs in different parts of the gastrointestinal tract. Perianal fistula is one of the most common complications in Crohn's disease [210,211]. It is also referred to as "inflammatory bowel disease" or "ulcerative colitis". It occurs when there is an abnormal interaction between the immune system of the intestine and the bacteria which is present on the surface of the gut [210-212]. The drugs used in treatment of Crohn's disease provide temporary relief to the patients; however, the toxicity related to these drugs may be short-term or long-term depending on the dosage [213]. The most common challenge which is faced by the researchers is effective management of Crohn's fistulas. However, it has been observed that MSCs derived from adipose tissue have the ability to differentiate into specialized cell types which in turn can be used to stimulate healing of Crohn's fistulas. Olmo et al. performed the phase I \& II clinical trial for patients suffering from Crohn's disease in order to test the safety and efficacy of MSCs transplantation. In phase I clinical trials, nine fistulas of four patients were inoculated with adipose tissue derived MSCs. Out of which, six fistulas healed completely (75\%) whereas the rest did not possess any healing effect. In phase II clinical trials, out of 24 patients, 17 showed healing of fistula. The above results indicate that MSCs derived from adipose tissue can be used as an effective therapeutic tool in treatment of Crohn's disease [213,214]. On the basis of the above experimental data, Olmo et al. used expanded adipose derived MSCs and stromal vascular fractionated cells against Crohn's disease in patients with enterocutaneous fistulas. These results indicate that adipose tissue derived MSCs were more effective as compared to stromal vascular fractionated cells for treatment of Crohn's disease [215]. Another phase I study was performed by Duijvestein et al. using bone marrow derived MSCs. Bone marrow MSCs were transplanted in ten patients. Any physical changes or side-effects were monitored on the basis of Crohn's Disease Activity Index (CDAI) scores. It was observed that bone marrow MSCs showed positive response in Crohn's disease patients without any adverse sideeffects [216]. Duijvestein et al. also showed that MSCs have the ability to interact with immune-suppressive drugs. It was observed that MSCs successfully differentiated into adipocytic and osteocytic cells without the interference of the drugs. These results indicate that MSCs can be effectively used in combination with immune-suppressive drugs in order to treat inflammatory bowel disease [217]. Similar study was performed by Ciccocioppo et al. using autologous bone marrow derived MSCs. Intrafistular injections of MSCs were administered to twelve patients. It was observed that expansion of MSCs was successful in all the patients and most of the patients showed reduced Crohn's fistulas. 
Rectal mucosa healing was observed without any severe complications. During treatment, the amount of circulating and mucosal $\mathrm{T}$ cells increased significantly and remained stable till the end of the study [218]. This experimental study shows that MSCs transplantation therapy is a feasible and safe technique in treating Crohn's fistulas. Many more clinical trials against Crohn's disease using MSCs have been initiated thereby giving hopes to the patients suffering from this dreadful disease.

\section{Cardiovascular diseases}

Many diseases are afflicting the population, out of which cardiovascular diseases are in the forefront because of the lifestyle adopted by the population. It is the leading cause of death worldwide. It has been estimated that in 2005, 17 million people died of cardiovascular diseases, out of which, 7.2 million people died of heart attacks whereas 5.7 million died due to stroke [219]. Toma et al. showed that human adult bone marrow Mesenchymal Stem Cells (MSCs) have the potential to differentiate into cardiomyocytes when it was transplanted into the myocardium of an adult murine. Human MSCs were isolated from the bone marrow of the healthy patients. These MSCs were then labelled using lac $\mathrm{Z}$ gene, which was then transplanted into an adult mice. After 1 week, the transplanted cells were showing similar morphological features as that of cardiomyocytes of the host. Immunohistochemical analysis showed the expression of various markers which are naturally present in the cardiomyocytes. This technique "Cellular Cardiomyoplasty" would be of great help in the treatment of cardiac diseases [220]. Kawada et al. performed similar kind of experiment, however, methodology was modified. 2 different studies were performed in order to study the origin of cardiomyocytes derived from bone marrow. In the first study, CD34- Sca-1+ c-kit+ bone marrow cells which were expressing Enhanced Green Fluorescent Protein (EGFP) were transplanted into mice which were lethally irradiated. Myocardial infarction was induced in mice and then treated with granulocyte colony-stimulating factor (G-CSF) in order to mobilize the cells to the affected myocardium area. It was observed that out of 100 models, 3 were positive for cells expressing EGFP and actinin indicating that these cells are derivatives of bone marrow cells [221]. Another study was performed by Kawada et al. in which MSCs and cardiomyogenic cells expressing EGFP were directly transplanted in the bone marrow of mice which was lethally irradiated. Myocardial infarction was induced in mice after which they were treated with G-CSF. It was observed that cardiomyogenic cells survived and transformed into cardiomyocytes. These results show that most of the bone marrow derived cardiomyocytes are MSCs which can be used in treatment of cardiovascular diseases [221]. Li et al. demonstrated that differentiation potential of MSCs into cardiomyocytes is dependent on Notch signal. This experiment was performed using a rat model induced with myocardial infarction. MSCs were labelled using DAPI. After 14 days, MSCs differentiation was observed using immunofluorescence technique. Both MSCs and cardiomyocytes were cultured in 4 different ways in vitro. It was observed that jagged-1 protein has the ability to activate Notch signal. This analysis indicates that Notch receptor is required for the differentiation of MSCs into cardiomyocytes which in turn can be used in treatment of cardiac diseases [222].

Rangappa et al. demonstrated the differentiation of MSCs isolated from adipose tissue into cardiomyocytes using reagent 5 -azacytidine at various concentrations and at different time intervals. It was observed that these stem cells can be differentiated into cardiomyocytes chemically [223]. Shim et al. showed transformation of MSCs into cardiomyocytes using 5-azacytidine ex vivo [224]. Potdar et al. isolated MSCs from human scalp biopsy. 5-azacytidine was used as an inducer which allowed the differentiation of MSCs into cardiomyocytes in vitro as shown in Figure 1 [225].

Similar studies were performed using chemical transformation method described in [226-234]. Wei et al. demonstrated the biological features of sub-population of MSCs. Single cell monoclonal technology was used to select 24 Mesenchymal stem cell clones. On induction using 5-azacytidine, out of 24 clones, 8 clones showed cardiomyocytelike appeareance and expressed certain cardiomyocytes molecular markers like $\alpha$-actin and cTnT similar to that of normal cardiomyocyte. This experimental data indicates that 8 MSCs clones were observed to have the ability to differentiate into cardiomyocyte, so this subgroup of MSCs can be referred to as cardiac progenitor cells. These cardiac stem cells would be of great help in developing a valuable therapeutic modality against cardiovascular diseases [235].

Zhao et al. along with their co-workers showed that lipid metabolite

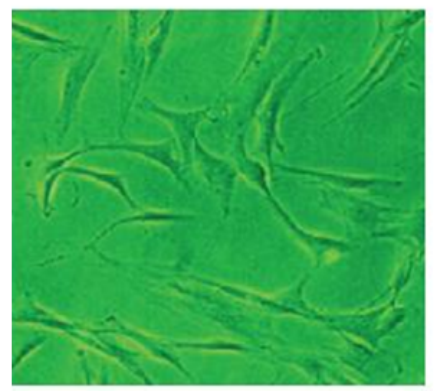

Figure 1a: Shows phase contrast micrographs of human dermal MSCs.

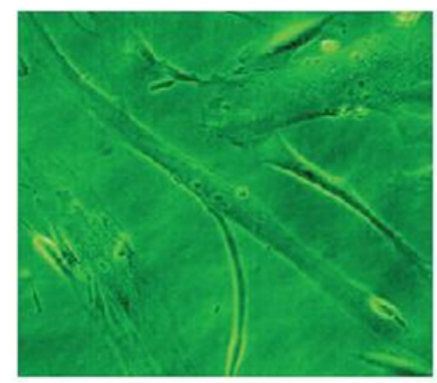

Figure $1 \mathrm{~b}$ : Shows $10 \mu \mathrm{M}$ 5-azacytidine treated slightly elongated human dermal MSCs cells on $14^{\text {th }}$ day after 48 hours.

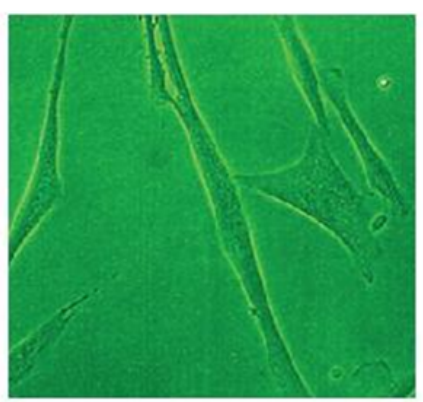

Figure 1c: Shows $20 \mu \mathrm{M}$ 5-azacytidine treated human dermal MSCs cells on $14^{\text {th }}$ day after 48 hours. The cells are showing cardiomyocyte-like phenotypic features [Potdar et al.]. 
Sphingosine-1-Phosphate acts as an inducer in differentiation of MSCs derived from the human umbilical cord into cardiomyocytes. In addition to it, they also designed a cardiac cell sheet which was engineered using poly ( $\mathrm{N}$-isopropylacrylamide) cell sheet technique. This technology will have wide range of potential applications in tissue engineering research in treatment of wide variety of cardiovascular diseases [236]. Huang et al. investigated whether the cyclic strain has the capability to induce differentiation of cardiomyocyte which is derived from bone marrow of rat MSCs. Cyclic strain have the ability to promote mechanical stimulation in cardiomyocyte in the body. The experimental results showed that treatment using a cyclic strain can induce cardiomyocyte differentiation of rat bone marrow MSCs [237]. Huang et al. examined whether the olfactory bulb of rat has the ability to differentiate into cardiomyocyte in vitro. The cells isolated from the olfactory bulb of a rat had fibroblast- like appearance. These cells were allowed to grow under 4 different conditions. Differentiation potential was analyzed using light microscopy, Western blotting, RTPCR and Immunofluorescence. These cells were found to express different molecular markers which were specific to the MSCs and cardiomyocytes. This experimental data indicates that the cells derived from the olfactory bulb of a rat have MSCs like features and can differentiate into cardiac cells [238]. Previous studies have shown that bone marrow derived stem cells have potential applications in treatment of ischemic cardiac disorders [239-241].

From the above findings, it is clear that a lot of research work has been carried out with animal models using cardiomyocytes derived from MSCs. However, the use of cardiomyocytes as a therapeutic tool in treatment of cardiovascular diseases is still a distant dream. Not until recently, Mayo Clinic declared the first U.S based stem cell clinical trials against congenital pediatric cardiovascular disease that is, hypoplastic left heart syndrome. Stem cells were isolated from the umbilical cord of the affected newborns and then injected into the heart muscle of the affected newborns. It was observed that stem cell therapy provided a feasible solution which will aid the affected newborns by regenerating new cardiac tissues in treatment of this fatal disease.

\section{MSCs use in Renal Transplantation}

Kidney transplantation involves substitution of failed kidneys with the functional one obtained from the donor. It is considered as an "elixir to life" for patients suffering from kidney disorders. Kidney transplantation has become the most preferred alternative to dialysis therapy in recent years. However, the limitations of kidney transplantation include use of medicines for the rest of an individual's life and risk of infection and rejection [242,243]. Morigi et al. and Togel et al. demonstrated the use of MSCs in order to repair and improve acute kidney failure [244,245]. Acute renal failure is the most frequently occurring disease which has high mortality rate. Herrera et al. showed that MSCs have the homing ability in the glycerol-induced acute renal failure mice model than in the kidney of a normal mice model. The results showed positive improvement in the affected kidney indicating that MSCs can be used as a therapeutic modality in treatment of acute renal failure [246]. It has been observed that MSCs also have the ability to repair the affected tissues caused due to reperfusion injury and renal ischemia [247]. Another study was performed using rat MSCs in order to treat the affected glomeruli there by making MSCs an ideal candidate for treatment against glomerular damage [248]. Remodelling of tissues is important in pathogenesis of acute renal failure. Grimm et al. tried to investigate the origin of MSCs in tissue remodelling especially the accumulation of MSCs in kidney transplants which were undergoing severe rejection. The results indicate that MSCs have the ability to colonize the renal allograft. This technique would be of great importance in preventing tissue rejection [249]. MSCs promises to provide therapeutic applications including prevention of tissue rejection [250-252]. The above findings suggest that MSCs can be used as an ideal therapeutic tool against various renal disorders as well as during kidney transplantations.

\section{Conclusion}

MSCs transplantation promises to transform the traditional use of embryonic stem cells to modern therapeutic applications. These therapeutic applications enhance the efficacy of treatment strategies against different types of diseases without any major complications. Immunomodulatory properties of MSCs has been very well proved in several animal and human studies and this property certainly help researchers to use these MSCs for therapies of various incurable diseases as well as specifically in autoimmune disorders and thus reduced the chances of transplant rejection. In recent years, MSC transplantation technology is found to be growing exponentially in the field of regenerative medicine. This technology gives us an opportunity to develop certain cell-based therapeutics that will be useful as a treatment modality against several other diseases in future. This review will give an insight overview of the use of human Mesenchymal Stem Cells (MSCs) in various regenerative therapies for neurological, cardiological, osteoarticular, auto-immune diseases and renal disorders. However, there is an urgent need of multiple clinical trials in order to bring this technology in the market so that it can be utilized by the masses for cure of many more diseases in human.

\section{Acknowledgement}

Authors wish to thank Management of Jaslok Hospital \& Research Centre Mumbai, India, for approval of stem cell research project no. 491, A/c 27814, which gave us an immense experience during last 3 years to work on development of mesenchymal stem cell lines and thus encouraged us to write this review on the use of MSCs for stem cell therapy.

\section{References}

1. Maximov AA (1909) Der Lymphozyt als gemeinsame zelle der verschiedenen Blutelemente in der embryonalen Entwicklung und im postfetalen Leben der Sa"ugetiere. Folia Haematol. (Leipzig) 8:125-141.

2. Till JE, McCulloch EA (1961) A direct measurements of the radiation sensitivity of normal mouse bone marrow cells. Radiat. Res. 14:1419-1430.

3. Siminovitch L, McCullouch EA, Till JE (1963) The Distribution of colony-forming cells among spleen colonies. J Cell Physiol 62: 327-336.

4. Moore M, Metcalf D (1970) Ontogeny of the haemopoietic system: yolk sac origin of in vivo and in vitro colony forming cells in the developing mouse embryo. Br J Haematol 18: 279-296.

5. McCulloch EA, Till JE (2005) Perspectives on the properties of stem cells. Nat Med 11: 1026-1028.

6. Pastrana E, Silva-Vargas V, Doetsch F (2011) Eyes wide open: a critical review of sphere-formation as an assay for stem cells. Cell Stem Cell 8: 486-498.

7. http://www.icr.org/i/pdf/imp/imp-344.pdf

8. Altman J, Das GD (1965) Autoradiographic and histological evidence of postnatal hippocampal neurogenesis in rats. J Comp Neurol 124: 319-335.

9. Altman J (1969) Autoradiographic and histological studies of postnata neurogenesis. IV. Cell proliferation and migration in the anterior forebrain, with special reference to persisting neurogenesis in the olfactory bulb. J Comp Neurol 137: 433-457.

10. Doetsch F, Caillé I, Lim DA, García-Verdugo JM, Alvarez-Buylla A (1999) Subventricular zone astrocytes are neural stem cells in the adult mammalian brain. Cell 97: 703-716

11. Bjornson CR, Rietze RL, Reynolds BA, Magli MC, Vescovi AL (1999) Turning brain into blood: a hematopoietic fate adopted by adult neural stem cells in vivo. Science 283: 534-537.

12. Woodbury D, Schwarz EJ, Prockop DJ, Black IB (2000) Adult rat and human 
bone marrow stromal cells differentiate into neurons. Journal of Neuroscience Research 61:364-370.

13. Galli R, Borello U, Gritti A, Minasi MG, Bjornson C, et al. (2000) Skeletal myogenic potential of human and mouse neural stem cells. Nat Neurosci 3: 986-991.

14. Palmer TD, Schwartz PH, Taupin P, Kaspar B, Stein SA, et al. (2001) Progenitor cells from human brain after death. Nature 411: 42-43.

15. Kruger GM, Mosher JT, Bixby S, Joseph N, Iwashita T, et al. (2002) Neural crest stem cells persist in the adult gut but undergo changes in self-renewal, neuronal subtype potential, and factor responsiveness. Neuron 35: 657-669.

16. Potdar PD, Sutar JP (2010) Establishment and Molecular Characterization of Mesenchymal Stem Cell Lines Derived From Human Visceral \& Subcutaneous Adipose Tissues- Journal of Stem Cells \& Regenerative Medicine 6: 1-10.

17. Potdar PD, D'souza SB (2011) Isolation of Oct4+, Nanog+ and SOX2mesenchymal cells from peripheral blood of a diabetes mellitus patient. Hum Cell 24: 51-55

18. Potdar PD, Subedi RP (2011) Defining Molecular Phenotypes of Mesenchyma and hematopoietic Stem Cells derived from Peripheral blood of Acute Lymphocytic Leukemia patients for regenerative stem cell therapy- Journal of Stem Cells \& Regenerative Medicine 7: 22-40.

19. Daniaiovia L, Lesna P, Havlas V, Teyssler P, Syrova Z, et al. (2007) Chondrogenic differentiation of human bone marrow and adipose tissuederived mesenchymal stem cells. J Appl Biomed 5: 139-150.

20. Fu YS, Cheng YC, Lin MY, Cheng H, Chu PM, et al. (2006) Conversion of human umbilical cord mesenchymal stem cells in Wharton's jelly to dopaminergic neurons in vitro: potential therapeutic application for Parkinsonism. Stem Cells 24: $115-124$

21. Weiss ML, Medicetty S, Bledsoe AR, Rachakatla RS, Choi M, et al. (2006) Human umbilical cord matrix stem cells: preliminary characterization and effect of transplantation in a rodent model of Parkinson's disease. Stem Cells 24 781-792.

22. Parker AM, Katz AJ (2006) Adipose-derived stem cells for the regeneration of damaged tissues. Expert Opin Biol Ther 6: 567-578.

23. Riordan NH, Ichim TE, Min WP, Wang H, Solano F, et al. (2009) Non-expanded adipose stromal vascular fraction cell therapy for multiple sclerosis. $\mathrm{J}$ Trans Med 7: 29

24. Krampera M, Marconi S, Pasini A, Galiè M, Rigotti G, et al. (2007) Induction of neural-like differentiation in human mesenchymal stem cells derived from bone marrow, fat, spleen and thymus. Bone 40: 382-390.

25. Anghileri E, Marconi S, Pignatelli A, Cifelli P, Galié M, et al. (2008) Neurona differentiation potential of human adipose-derived mesenchymal stem cells. Stem Cells Dev 17: 909-916.

26. Constantin G, Marconi S, Rossi B, Angiari S, Calderan L, et al. (2009) Adiposederived mesenchymal stem cells ameliorate chronic experimental autoimmune encephalomyelitis. Stem Cells 27: 2624-2635.

27. Hedayatpour A, Ragerdi I, Pasbakhsh P, Kafami L, Atlasi N, et al. (2013) Promotion of remyelination by adipose mesenchymal stem cell transplantation in a cuprizone model of multiple sclerosis. Cell J 15: 142-151.

28. Mohyeddin Bonab M, Yazdanbakhsh S, Lotfi J, Alimoghaddom K, Talebian F, et al. (2007) Does mesenchymal stem cell therapy help multiple sclerosis patients? Report of a pilot study. Iran J Immunol 4: 50-57.

29. Gussoni E, Soneoka Y, Strickland CD, Buzney EA, Khan MK, et al. (1999) Dystrophin expression in the $\mathrm{mdx}$ mouse restored by stem cell transplantation. Nature 401: 390-394.

30. Sata M, Saiura A, Kunisato A, Tojo A, Okada S, et al. (2002) Hematopoietic stem cells differentiate into vascular cells that participate in the pathogenesis of atherosclerosis. Nat Med 8: 403-409.

31. Lagasse E, Connors H, Al-Dhalimy M, Reitsma M, Dohse M, et al. (2000) Purified hematopoietic stem cells can differentiate into hepatocytes in vivo. Nat Med 6: 1229-1234.

32. Eglitis MA, Mezey E (1997) Hematopoietic cells differentiate into both microglia and macroglia in the brains of adult mice. Proc Natl Acad Sci USA 94: 40804085

33. Orlic D, Kajstura J, Chimenti S, Jakoniuk I, Anderson SM, et al. (2001) Bone marrow cells regenerate infarcted myocardium. Nature 410: 701-705.
34. Ferrari G, Cusella-De Angelis G, Coletta M, Paolucci E, Stornaiuolo A, et at. (1998) Muscle regeneration by bone marrow-derived myogenic progenitors. Science 279: 1528-1530

35. Tomita M, Adachi Y, Yamada H, Takahashi K, Kiuchi K, et al. (2002) Bone marrow-derived stem cells can differentiate into retinal cells in injured rat retina. Stem Cells 20: 279-283.

36. Tang H, Guo Z, Zhang M, Wang J, Chen G, et al. (2006) Endothelial stroma programs hematopoietic stem cells to differentiate into regulatory dendritic cells through IL-10. Blood 108: 1189-1197.

37. Murrell W, Féron F, Wetzig A, Cameron N, Splatt K, et al. (2005) Multipotent stem cells from adult olfactory mucosa. Dev Dyn 233: 496-515.

38. Huard JM, Youngentob SL, Goldstein BJ, Luskin MB, Schwob JE (1998) Adult olfactory epithelium contains multipotent progenitors that give rise to neurons and non-neural cells. J Comp Neurol 400: 469-486.

39. Murrell W, Wetzig A, Donnellan M, Féron F, Burne T, et al. (2008) Olfactory mucosa is a potential source for autologous stem cell therapy for Parkinson's disease. Stem Cells 26: 2183-2192.

40. Blanpain C, Horsley V, Fuchs E (2007) Epithelial stem cells: turning over new leaves. Cell 128: 445-458.

41. Hall PA, Watt FM (1989) Stem cells: the generation and maintenance of cellular diversity. Development 106: 619-633.

42. Liu S, Dontu G, Wicha M (2005) Mammary stem cells, self-renewal pathways, and carcinogenesis. Breast Cancer Res 7: 86-95.

43. Holtzer H (1978) Cell lineages, stem cells and the 'quantal' cell cycle concept. In: Stem cells and tissue homeostasis. Eds: B.I. Lord, C.S. Potten, and R.J. Cole.

44. Leblond CP (1964) Classification of cell population on the basis of their proliferative behavior. National Cancer Inst Monogr 14: 119-150.

45. Robey PG (2000) Stem cells near the century mark. J Clin Invest 105: 1489 1491.

46. Brazelton TR, Rossi FM, Keshet GI, Blau HM (2000) From marrow to brain expression of neuronal phenotypes in adult mice. Science 290: 1775-1779.

47. Krause DS, Theise ND, Collector MI, Henegariu O, Hwang S, et al. (2001) Multi-organ, multi-lineage engraftment by a single bone marrow-derived stem cell. Cell 105: 369-377

48. Chamberlain G, Fox J, Ashton B, Middleton J (2007) Concise review: mesenchymal stem cells: their phenotype, differentiation capacity, immunological features, and potential for homing. Stem Cells 25: 2739-2749.

49. Potdar PD, Chougule SR (2011) - Establishment and Molecular Characterization of Breast Cancer Mesenchymal Stem Cell Line derived from Human Nonmetastasis Breast Cancer Tumor. Stem Cell Discovery 1: 21-28.

50. Potdar PD, Kumar K S ( 2013)- Establishment and molecular characterization of human dermal mesenchymal-like stem cells derived from human scalp biopsy of androgenetic alopecia patient Stem Cell Discovery 3: 77-82

51. Lee RH, Kim B, Choi I, Kim H, Choi HS, et al. (2004) Characterization and expression analysis of mesenchymal stem cells from human bone marrow and adipose tissue. Cell Physiol Biochem 14: 311-324.

52. Rostovskaya M, Anastassiadis K (2012) Differential expression of surface markers in mouse bone marrow mesenchymal stromal cell subpopulations with distinct lineage commitment. PLOS One 7: e51221.

53. P M, S H, R M, M G, W S K (2011) Adult mesenchymal stem cells and cell surface characterization - a systematic review of the literature. Open Orthop J 5: 253-260.

54. Parte S, Bhartiya D, Telang J, Daithankar V, Salvi V, et al. (2011) Detection, characterization, and spontaneous differentiation in vitro of very small embryonic-like putative stem cells in adult mammalian ovary. Stem Cells Dev 20: $1451-1464$

55. Kim DH, Yoo KH, Choi KS, Choi J, Choi SY, et al. (2005) Gene expression profile of cytokine and growth factor during differentiation of bone marrowderived mesenchymal stem cell. Cytokine 31: 119-126.

56. Majumdar MK, Thiede MA, Haynesworth SE, Bruder SP, Gerson SL (2000) Human marrow-derived mesenchymal stem cells (MSCs) express hematopoietic cytokines and support long-term hematopoiesis when differentiated toward stromal and osteogenic lineages. J Hematother Stem Cell Res 9: 841-848. 
57. Liu CH, Hwang SM (2005) Cytokine interactions in mesenchymal stem cells from cord blood. Cytokine 32: 270-279.

58. Ponte AL, Marais E, Gallay N, Langonné A, Delorme B, et al. (2007) The in vitro migration capacity of human bone marrow mesenchymal stem cells: comparison of chemokine and growth factor chemotactic activities. Stem Cells 25: $1737-1745$.

59. Silva WA Jr, Covas DT, Panepucci RA, Proto-Siqueira R, Siufi JL, et al. (2003) The profile of gene expression of human marrow mesenchymal stem cells. Stem Cells 21: 661-669.

60. Mayer H, Bertram H, Lindenmaier W, Korff T, Weber H, et al. (2005) Vascula endothelial growth factor (VEGF-A) expression in human mesenchymal stem cells: autocrine and paracrine role on osteoblastic and endothelia differentiation. J Cell Biochem 95: 827-839.

61. Ji JF, He BP, Dheen ST, Tay SS (2004) Interactions of chemokines and chemokine receptors mediate the migration of mesenchymal stem cells to the impaired site in the brain after hypoglossal nerve injury. Stem Cells 22: 415427

62. Sordi V, Malosio ML, Marchesi F, Mercalli A, Melzi R, et al. (2005) Bone marrow mesenchymal stem cells express a restricted set of functionally active chemokine receptors capable of promoting migration to pancreatic islets. Blood 106: 419-427.

63. Ringe J, Strassburg S, Neumann K, Endres M, Notter M, et al. (2007) Tow ards in situ tissue repair: human mesenchymal stem cells express chemokine receptors CXCR1, CXCR2 and CCR2, and migrate upon stimulation with CXCL8 but not CCL2. J Cell Biochem 101: 135-146.

64. Muir H (1995) The chondrocyte, architect of cartilage. Biomechanics, structure function and molecular biology of cartilage matrix macromolecules. Bioessays 17: $1039-1048$

65. Johnstone B, Hering TM, Caplan Al, Goldberg VM, Yoo JU (1998) In vitro chondrogenesis of bone marrow-derived mesenchymal progenitor cells. Exp Cell Res 238: 265-272.

66. Fortier LA, Nixon AJ, Williams J, Cable CS (1998) Isolation and chondrocytic differentiation of equine bone marrow-derived mesenchymal stem cells. Am J Vet Res 59: 1182-1187.

67. Barry F, Boynton RE, Liu B, Murphy JM (2001) Chondrogenic differentiation of mesenchymal stem cells from bone marrow: differentiation-dependent gene expression of matrix components. Exp Cell Res 268: 189-200.

68. Im GI, Kim DY, Shin JH, Hyun CW, Cho WH (2001) Repair of cartilage defect in the rabbit with cultured mesenchymal stem cells from bone marrow. J Bone Joint Surg Br 83: 289-294.

69. Mackay AM, Beck SC, Murphy JM, Barry FP, Chichester CO, et al. (1998) Chondrogenic differentiation of cultured human mesenchymal stem cells from marrow. Tissue Eng 4: 415-428.

70. Laurencin CT, Ambrosio AM, Borden MD, Cooper JA Jr (1999) Tissue engineering: orthopedic applications. Annu Rev Biomed Eng 1: 19-46.

71. Hardingham T, Tew S, Murdoch A (2002) Tissue engineering: chondrocytes and cartilage. Arthritis Res 4 Suppl 3: S63-68.

72. Langer R, Vacanti JP (1993) Tissue engineering. Science 260: 920-926.

73. Vacanti CA, Vacanti JP (2000) The science of tissue engineering. Orthop Clin North Am 31: 351-356.

74. Vacanti JP, Langer R (1999) Tissue engineering: the design and fabrication of living replacement devices for surgical reconstruction and transplantation. Lancet 354 Suppl 1: SI32-SI34.

75. Gupta SK, Sharma C, Dinda AK, Ray AK, Mishra NC (2012) Tooth tissue engineering: potential and piffalls. Journal of Biomimetics, Biomaterials and Tissue Engineering 12: 59-81.

76. Gupta SK, Dinda AK, Potdar PD, Mishra NC (2013) Modification of decellularized goat-lung scaffold with chitosan/nanohydroxyapatite composite for bone tissue engineering applications. Biomed Res Int 2013: 651945.

77. Gupta SK, Dinda AK, Potdar PD, Mishra NC (2013) Fabrication and characterization of scaffold from cadaver goat-lung tissue for skin tissue engineering applications. Mater Sci Eng C Mater Biol Appl 33: 4032-4038.

78. Richardson SM, Curran JM, Chen R, Vaughan-Thomas A, Hunt JA, et al. (2006) The differentiation of bone marrow mesenchymal stem cells into chondrocytelike cells on poly-L-lactic acid (PLLA) scaffolds. Biomaterials 27: 4069-4078.
79. Indrawattana N, Chen G, Tadokoro M, Shann LH, Ohgushi $\mathrm{H}$, et at. (2004) Growth factor combination for chondrogenic induction from human mesenchymal stem cell. Biochem Biophys Res Commun 320: 914-919.

80. Schmitt B, Ringe J, Häupl T, Notter M, Manz R, et al. (2003) BMP2 initiates chondrogenic lineage development of adult human mesenchymal stem cells in high-density culture. Differentiation 71: 567-577.

81. Bai X, Xiao Z, Pan Y, Hu J, Pohl J, et al. (2004) Cartilage-derived morphogenetic protein-1 promotes the differentiation of mesenchymal stem cells into chondrocytes. Biochem Biophys Res Commun 325: 453-460.

82. Arikawa T, Matsukawa A, Watanabe K, Sakata KM, Seki M, et al. (2009) Galectin-9 accelerates transforming growth factor beta3-induced differentiation of human mesenchymal stem cells to chondrocytes. Bone 44: 849-857.

83. Maumus M, Manferdini C, Toupet K, Peyrafitte JA, Ferreira R, et al. (2013) Adipose mesenchymal stem cells protect chondrocytes from degeneration associated with osteoarthritis. Stem Cell Res 11: 834-844.

84. Matsuda C, Takagi M, Hattori T, Wakitani S, Yoshida T (2005) Differentiation of Human Bone Marrow Mesenchymal Stem Cells to Chondrocytes fo Construction of Three-dimensional Cartilage Tissue. Cytotechnology 47: 11-17.

85. Centeno CJ, Busse D, Kisiday J, Keohan C, Freeman M, et al. (2008) Increased knee cartilage volume in degenerative joint disease using percutaneously implanted, autologous mesenchymal stem cells. Pain Physician 11: 343-353.

86. Centeno CJ, Busse D, Kisiday J, Keohan C, Freeman M, et al. (2008) Regeneration of meniscus cartilage in a knee treated with percutaneously implanted autologous mesenchymal stem cells. Med Hypotheses 71: 900-908.

87. Davatchi F, Abdollahi BS, Mohyeddin M, Shahram F, Nikbin B (2011) Mesenchymal stem cell therapy for knee osteoarthritis. Preliminary report of four patients. Int J Rheum Dis 14: 211-215.

88. Koh YG, Choi YJ (2012) Infrapatellar fat pad-derived mesenchymal stem cell therapy for knee osteoarthritis. Knee 19: 902-907.

89. Moore DJ, West AB, Dawson VL, Dawson TM (2005) Molecular pathophysiology of Parkinson's disease. Annu Rev Neurosci 28: 57-87.

90. Lindvall O (2003) Stem cells for cell therapy in Parkinson's disease. Pharmacol Res 47: 279-287.

91. Levy YS, Stroomza M, Melamed E, Offen D (2004) Embryonic and adult stem cells as a source for cell therapy in Parkinson's disease. J Mol Neurosci 24 353-386.

92. Takahashi J (2007) Stem cell therapy for Parkinson's disease. Expert Rev Neurother 7: 667-675.

93. Wang Y, Chen S, Yang D, Le WD (2007) Stem cell transplantation: a promising therapy for Parkinson's disease. J Neuroimmune Pharmacol 2: 243-250.

94. Li Y, Chen J, Wang L, Zhang L, Lu M, et al. (2001) Intracerebral transplantation of bone marrow stromal cells in a 1-methyl-4-phenyl-1,2,3,6-tetrahydropyridine mouse model of Parkinson's disease. Neurosci Lett 316: 67-70.

95. Chao YX, He BP, Tay SSW (2009) Mesenchymal stem cell transplantation attenuates blood brain barrier damage and neuroinflammation and protects dopaminergic neurons against MPTP toxicity in the substantia nigra in a mode of Parkinson's disease. Journal of Neuroimmunology 216: 39-50.

96. Offen D, Barhum Y, Levy YS, Burshtein A, Panet H, et al. (2007) Intrastriata transplantation of mouse bone marrow-derived stem cells improves moto behavior in a mouse model of Parkinson's disease. J Neural Transm Suppl: 133-143.

97. Blondheim NR, Levy YS, Ben-Zur T, Burshtein A, Cherlow T, et al. (2006) Human mesenchymal stem cells express neural genes, suggesting a neural predisposition. Stem Cells Dev 15: 141-164.

98. Park HJ, Lee PH, Bang OY, Lee G, Ahn YH (2008) Mesenchymal stem cells therapy exerts neuroprotection in a progressive animal model of Parkinson's disease. J Neurochem 107: 141-151.

99. Zappia E, Casazza S, Pedemonte E, Benvenuto F, Bonanni I, et al. (2005) Mesenchymal stem cells ameliorate experimental autoimmune encephalomyelitis inducing T-cell anergy. Blood 106: 1755-1761.

100. Gerdoni E, Gallo B, Casazza S, Musio S, Bonanni I, et al. (2007) Mesenchymal stem cells effectively modulate pathogenic immune response in experimental autoimmune encephalomyelitis. Ann Neurol 61: 219-227.

101. Guo J, Lin GS, Bao CY, Hu ZM, Hu MY (2007) Anti-inflammation role for 
mesenchymal stem cells transplantation in myocardial infarction. Inflammation 30: $97-104$

102. Kim YJ, Park HJ, Lee G, Bang OY, Ahn YH, et al. (2009) Neuroprotective effects of human mesenchymal stem cells on dopaminergic neurons through anti-inflammatory action. Glia 57: 13-23.

103.Schwarz EJ, Alexander GM, Prockop DJ, Azizi SA (1999) Multipotentia marrow stromal cells transduced to produce L-DOPA: engraftment in a rat model of Parkinson disease. Hum Gene Ther 10: 2539-2549.

104.Lu L, Zhao C, Liu Y, Sun X, Duan C, et al. (2005) Therapeutic benefit of THengineered mesenchymal stem cells for Parkinson's disease. Brain Res Brain Res Protoc 15: 46-51.

105. Pisati F, Bossolasco P, Meregalli M, Cova L, Belicchi M, et al. (2007) Induction of neurotrophin expression via human adult mesenchymal stem cells: implication for cell therapy in neurodegenerative diseases. Cell Transplant 16: 41-55.

106. Xiong N, Zhang Z, Huang J, Chen C, Zhang Z, et al. (2011) VEGF-expressing human umbilical cord mesenchymal stem cells, an improved therapy strategy for Parkinson's disease. Gene Ther 18: 394-402.

107. Hayashi T, Wakao S, Kitada M, Ose T, Watabe H, et al. (2013) Autologous mesenchymal stem cell-derived dopaminergic neurons function in parkinsonian macaques. J Clin Invest 123: 272-284.

108. Venkataramana NK, Kumar SK, Balaraju S, Radhakrishnan RC, Bansal A, et al. (2010) Open-labeled study of unilateral autologous bone-marrow-derived mesenchymal stem cell transplantation in Parkinson's disease. Transl Res 155: $62-70$.

109. Venkataramana NK, Pal R, Rao SA, Naik AL, Jan M, et al. (2012) Bilateral transplantation of allogenic adult human bone marrow-derived mesenchymal stem cells into the subventricular zone of Parkinson's disease: a pilot clinical study. Stem Cells Int 2012: 931902.

110. Gutekunst CA, Norflus F, Hersch SM (2000) Recent advances in Huntington's disease. Curr Opin Neurol 13: 445-450.

111. Jenkins JB, Conneally PM (1989) The paradigm of Huntington disease. Am J Hum Genet 45: 169-175.

112. Huntington's Disease Collaborative Research Group (1993). A nove gene containing a trinucleotide repeats that is expanded and unstable on Huntington's disease chromosomes. Cell 72:971-983.

113. Gutekunst CA, Li SH, Yi H, Mulroy JS, Kuemmerle S, et al. (1999) Nuclear and neuropil aggregates in Huntington's disease: relationship to neuropathology. J Neurosci 19: 2522-2534.

114. Coyle JT, Schwarcz R (1976) Lesion of striatal neurones with kainic acid provides a model for Huntington's chorea. Nature 263: 244-246.

115. Isacson O, Brundin P, Kelly PA, Gage FH, Björklund A (1984) Functional neuronal replacement by grafted striatal neurones in the ibotenic acid-lesioned rat striatum. Nature 311: 458-460.

116. Beal MF, Kowall NW, Ellison DW, Mazurek MF, Swartz KJ, et al. (1986) Replication of the neurochemical characteristics of Huntington's disease by quinolinic acid. Nature 321: 168-171.

117. Sanberg PR, Calderon SF, Giordano M, Tew JM, Norman AB (1989) The quinolinic acid model of Huntington's disease: locomotor abnormalities. Exp Neurol 105: 45-53.

118. Lin Y-T, Chern Y, James Shen C-KJ, Wen H-L, Chang Y-C, et al. (2011) Human Mesenchymal Stem Cells Prolong Survival and Ameliorate Motor Deficit through Trophic Support in Huntington's Disease Mouse Models. PLOS ONE 6: e22924.

119. Rossignol J, Boyer C, Lévèque $X$, Fink KD, Thinard R, et al. (2011) Mesenchymal stem cell transplantation and DMEM administration in a 3NP rat model of Huntington's disease: morphological and behavioral outcomes. Behav Brain Res 217: 369-378.

120. Jiang $Y$, Lv H, Huang $S$, Tan $H$, Zhang $Y$, et al. (2011) Bone marrow mesenchymal stem cells can improve the motor function of a Huntington's disease rat model. Neurol Res 33: 331-337.

121. Sadan O, Shemesh N, Barzilay R, Bahat-Stromza M, Melamed E, et al. (2008) Migration of neurotrophic factors-secreting mesenchymal stem cells toward a quinolinic acid lesion as viewed by magnetic resonance imaging. Stem Cells 26: 2542-2551.
22. Sadan O, Shemesh N, Barzilay R, Dadon-Nahum M, Blumenfeld-Katzir T, et al. (2012) Mesenchymal stem cells induced to secrete neurotrophic factors attenuate quinolinic acid toxicity: a potential therapy for Huntington's disease. Exp Neurol 234: 417-427.

123.Sadan O, Melamed E, Offen D (2012) Intrastriatal transplantation of neurotrophic factor-secreting human mesenchymal stem cells improves motor function and extends survival in R6/2 transgenic mouse model for Huntington's disease. PLOS Curr 4: e4f7f6dc013d4e.

124. Bantubungi K, Blum D, Cuvelier L, Wislet-Gendebien S, Rogister B, et al. (2008) Stem cell factor and mesenchymal and neural stem cell transplantation in a rat model of Huntington's disease. Mol Cell Neurosci 37: 454-470.

125. Dey ND, Bombard MC, Roland BP, Davidson S, Lu M, et al. (2010) Genetically engineered mesenchymal stem cells reduce behavioral deficits in the YAC 128 mouse model of Huntington's disease. Behav Brain Res 214: 193-200.

126. Olson SD, Pollock K, Kambal A, Cary W, Mitchell GM, et al. (2012) Genetically engineered mesenchymal stem cells as a proposed therapeutic for Huntington's disease. Mol Neurobiol 45: 87-98.

127. Lee ST, Chu K, Park JE, Lee K, Kang L, et al. (2005) Intravenous administration of human neural stem cells induces functional recovery in Huntington's disease rat model. Neurosci Res 52: 243-249.

128. Mulder DW (1982) Clinical limits of amyotrophic lateral sclerosis. Adv Neurol 36: $15-22$.

129. Pasinelli P, Brown RH (2006) Molecular biology of amyotrophic lateral sclerosis: insights from genetics. Nat Rev Neurosci 7: 710-723.

130. Mazzini L, Fagioli F, Boccaletti R, Mareschi K, Oliveri G, et al. (2003) Stem cell therapy in amyotrophic lateral sclerosis: a methodological approach in humans. Amyotroph Lateral Scler Other Motor Neuron Disord 4: 158-161.

131. Mazzini L, Mareschi K, Ferrero I, Vassallo E, Oliveri G, et al. (2006) Autologous mesenchymal stem cells: clinical applications in amyotrophic lateral sclerosis. Neurol Res 28: 523-526.

132. Mazzini L, Mareschi K, Ferrero I, Vassallo E, Oliveri G, et al. (2008) Stem cell treatment in Amyotrophic Lateral Sclerosis. J Neurol Sci 265: 78-83.

133. Mazzini L, Ferrero I, Luparello V, Rustichelli D, Gunetti M, et al. (2010) Mesenchymal stem cell transplantation in amyotrophic lateral sclerosis: A Phase I clinical trial. Exp Neurol 223: 229-237.

134. Karussis D, Karageorgiou C, Vaknin-Dembinsky A, Gowda-Kurkalli B, Gomori JM, et al. (2010) Safety and immunological effects of mesenchymal stem cell transplantation in patients with multiple sclerosis and amyotrophic lateral sclerosis. Arch Neurol 67: 1187-1194.

135. Rosen DR, et al. (1993) Mutations in Cu/Zn superoxide dismutase gene are associated with familial amyotrophic lateral sclerosis. Nature 362:59-62.

136. Vercelli A, Mereuta OM, Garbossa D, Muraca G, Mareschi K, et al. (2008) Human mesenchymal stem cell transplantation extends survival, improves motor performance and decreases neuroinflammation in mouse model of amyotrophic lateral sclerosis. Neurobiology of Disease 31: 395-405.

137. Kim H, Kim HY, Choi MR, Hwang S, Nam KH, et al. (2010) Dose-dependent efficacy of ALS-human mesenchymal stem cells transplantation into cisterna magna in SOD1-G93A ALS mice. Neurosci Lett 468: 190-194.

138. Boucherie C, Schafer S, Lavand'homme P, Maloteaux J-M and Hermans E (2009) Chimerization of astroglial population in the lumbar spinal cord after mesenchymal stem cell transplantation prolongs survival in a rat model of amyotrophic lateral sclerosis. Journal of Neuroscience Research 87: 2034 2046.

139. Boucherie C, Caumont A-S, Maloteaux J-M, Hermans E (2008) In vitro evidence for impaired neuroprotective capacities of adult mesenchymal stem cells derived from a rat model of familial amyotrophic lateral sclerosis (hSOD1G93A). Experimental Neurology 212: 557-561.

140. Nicaise C, Mitrecic D, Pochet R (2011) Brain and spinal cord affected by amyotrophic lateral sclerosis induce differential growth factors expression in rat mesenchymal and neural stem cells. Neuropathol Appl Neurobiol 37: 179 188.

141.http://www.biosciencetechnology.com/articles/2013/05/fda-approved-stemcell-trial-dramatically-slows-als\#.UgUONW3da8t

142. http://blogs.als.net/post/ISSCR-2013-ALS-Stem-to-Stern.aspx

143.http://www.emcell.com/en/list_of_diseases/als.htm 
144. Bang OY, Lee JS, Lee PH, Lee G (2005) Autologous mesenchymal stem cell transplantation in stroke patients. Ann Neurol 57: 874-882

145. Lee JS, Hong JM, Moon GJ, Lee PH, Ahn YH, et al. (2010) A long-term followup study of intravenous autologous mesenchymal stem cell transplantation in patients with ischemic stroke. Stem Cells 28: 1099-1106.

146. Liu YP, Seçkin H, Izci Y, Du ZW, Yan YP, et al. (2009) Neuroprotective effects of mesenchymal stem cells derived from human embryonic stem cells in transient focal cerebral ischemia in rats. J Cereb Blood Flow Metab 29: 780791.

147. Honmou O, Onodera R, Sasaki M, Waxman SG, Kocsis JD (2012) Mesenchymal stem cells: therapeutic outlook for stroke. Trends Mol Med 18: 292-297.

148. Heo JS, Choi SM, Kim HO, Kim EH, You J, et al. (2013) Neura transdifferentiation of human bone marrow mesenchymal stem cells on hydrophobic polymer-modified surface and therapeutic effects in an animal model of ischemic stroke. Neuroscience 238: 305-318.

149. Liu N, Zhang Y, Fan L, Yuan M, Du H, et al. (2011) Effects of transplantation with bone marrow-derived mesenchymal stem cells modified by Survivin on experimental stroke in rats. J Transl Med 9: 105.

150. Koh SH, Kim KS, Choi MR, Jung KH, Park KS, et al. (2008) Implantation of human umbilical cord-derived mesenchymal stem cells as a neuroprotective therapy for ischemic stroke in rats. Brain Res 1229: 233-248.

151. Chopp M, Li Y (2002) Treatment of neural injury with marrow stromal cells Lancet Neurol 1: 92-100.

152. Li WY, Choi YJ, Lee PH, Huh K, Kang YM, et al. (2008) Mesenchymal stem cells for ischemic stroke: changes in effects after ex vivo culturing. Cell Transplant 17: 1045-1059.

153. Abrahams JM, Gokhan S, Flamm ES, Mehler MF (2004) De novo neurogenesis and acute stroke: are exogenous stem cells really necessary? Neurosurgery 54: 150-155.

154. Lindvall O, Kokaia Z, Martinez-Serrano A (2004) Stem cell therapy for human neurodegenerative disorders-how to make it work. Nat Med 10 Suppl: S42-50.

155. Boomsma RA, Geenen DL (2012) Mesenchymal stem cells secrete multiple cytokines that promote angiogenesis and have contrasting effects on chemotaxis and apoptosis. PLOS One 7: e35685.

156. Dharmasaroja P (2009) Bone marrow-derived mesenchymal stem cells for the treatment of ischemic stroke. J Clin Neurosci 16: 12-20.

157. Yoo SW, Kim SS, Lee SY, Lee HS, Kim HS, et al. (2008) Mesenchymal stem cells promote proliferation of endogenous neural stem cells and survival of newborn cells in a rat stroke model. Exp Mol Med 40: 387-397.

158. Bliss TM, Andres RH, Steinberg GK (2010) Optimizing the success of cell transplantation therapy for stroke. Neurobiol Dis 37: 275-283.

159. Parekkadan B, Milwid JM (2010) Mesenchymal stem cells as therapeutics. Annu Rev Biomed Eng 12: 87-117.

160. Chen J, Li Y, Wang L, Zhang Z, Lu D, et al. (2001) Therapeutic benefit of intravenous administration of bone marrow stromal cells after cerebral ischemia in rats. Stroke 32: 1005-1011.

161. Tsai LK, Leng Y, Wang Z, Leeds $P$, Chuang DM (2010) The mood stabilizers valproic acid and lithium enhance mesenchymal stem cell migration via distinct mechanisms. Neuropsychopharmacology 35: 2225-2237.

162. Tsai LK, Wang Z, Munasinghe J, Leng Y, Leeds $P$, et al. (2011) Mesenchyma stem cells primed with valproate and lithium robustly migrate to infarcted regions and facilitate recovery in a stroke model. Stroke 42: 2932-2939.

163. Kim D, Chun BG, Kim YK, Lee YH, Park CS, et al. (2008) In vivo tracking of human mesenchymal stem cells in experimental stroke. Cell Transplant 16: 1007-1012.

164. Shyu WC, Chen CP, Lin SZ, Lee YJ, Li H (2007) Efficient tracking of non-ironlabeled mesenchymal stem cells with serial MRI in chronic stroke rats. Stroke 38: 367-374.

165. Pavlichenko N, Sokolova I, Vijde S, Shvedova E, Alexandrov G, et al. (2008) Mesenchymal stem cells transplantation could be beneficial for treatment of experimental ischemic stroke in rats. Brain Res 1233: 203-213.

166. Mahmood A, Lu D, Chopp M (2004) Intravenous administration of marrow stromal cells (MSCs) increases the expression of growth factors in rat brain after traumatic brain injury. J Neurotrauma 21: 33-39.

167. van Velthoven CT, Sheldon RA, Kavelaars A, Derugin N, Vexler ZS, et al (2013) Mesenchymal stem cell transplantation attenuates brain injury after neonatal stroke. Stroke 44: 1426-1432.

168.http://www.nhs.uk/news/2013/05May/Pages/Stem-cell-stroke-treatment-trialresults-show-promise.aspx

169. van Belle TL, Coppieters KT, von Herrath MG (2011) Type 1 diabetes: etiology, immunology, and therapeutic strategies. Physiol Rev 91: 79-118.

170. Hussain MA, Theise ND (2004) Stem-cell therapy for diabetes mellitus. Lancet 364: 203-205.

171. Vija L, Farge D, Gautier JF, Vexiau P, Dumitrache C, et al. (2009) Mesenchymal stem cells: Stem cell therapy perspectives for type 1 diabetes. Diabetes Metab 35: 85-93.

172. Chen LB, Jiang XB, Yang $L$ (2004) Differentiation of rat marrow mesenchymal stem cells into pancreatic islet beta-cells. World J Gastroenterol 10: 30163020 .

173. Chao KC, Chao KF, Fu YS, Liu SH (2008) Islet-like clusters derived from mesenchymal stem cells in Wharton's Jelly of the human umbilical cord for transplantation to control type 1 diabetes. PLOS One 3: e1451.

174. Urbán VS, Kiss J, Kovács J, Gócza E, Vas V, et al. (2008) Mesenchymal stem cells cooperate with bone marrow cells in therapy of diabetes. Stem Cells 26 : 244-253.

175.Sun Y, Chen L, Hou XG, Hou WK, Dong JJ, et al. (2007) Differentiation of bone marrow-derived mesenchymal stem cells from diabetic patients into insulin-producing cells in vitro. Chin Med J (Engl) 120: 771-776.

176. Ramiya VK, Maraist M, Arfors KE, Schatz DA, Peck AB, et al. (2000) Reversa of insulin-dependent diabetes using islets generated in vitro from pancreatic stem cells. Nat Med 6: 278-282.

177. Xu J, Lu Y, Ding F, Zhan X, Zhu M, et al. (2007) Reversal of diabetes in mice by intrahepatic injection of bone-derived GFP-murine mesenchymal stem cells infected with the recombinant retrovirus-carrying human insulin gene. World $\mathrm{J}$ Surg 31: 1872-1882.

178. Calne R (2005) Cell transplantation for diabetes. Philos Trans R Soc Lond B Biol Sci 360: 1769-1774.

179. Ezquer FE, Ezquer ME, Parrau DB, Carpio D, Yañez AJ, et al. (2008) Systemic administration of multipotent mesenchymal stromal cells reverts hyperglycemia and prevents nephropathy in type 1 diabetic mice. Biol Blood Marrow Transplant 14: 631-640.

180. Trivedi HL, Vanikar AV, Thakker U, Firoze A, Dave SD, et al. (2008) Human adipose tissue-derived mesenchymal stem cells combined with hematopoietic stem cell transplantation synthesize insulin. Transplant Proc 40: 1135-1139.

181. Kidd PM (2001) Multiple sclerosis, an autoimmune inflammatory disease: prospects for its integrative management. Altern Med Rev 6: 540-566.

182. Karussis D, Kassis I, Kurkalli BGS, Slavin S (2007). Immunomodulation and neuroprotection with mesenchymal bone marrow stem cells (MSCs): A proposed treatment for multiple sclerosis and other neuroimmunological/ neurodegenerative diseases. Journal of the Neurological Sciences 265:131 135.

183. Bai L, Lennon DP, Eaton V, Maier K, Caplan Al, et al. (2009) Human bone marrow-derived mesenchymal stem cells induce Th2-polarized immune response and promote endogenous repair in animal models of multiple sclerosis. Glia 57: 1192-1203.

184. Bai L, Lennon DP, Caplan Al, DeChant A, Hecker J, et al. (2012) Hepatocyte growth factor mediates mesenchymal stem cellâ€"induced recovery in multiple sclerosis models. Nat Neurosci 15: 862-870.

185. Kassis I, Grigoriadis N, Gowda-Kurkalli B, Mizrachi-Kol R, Ben-Hur T, et al (2008) Neuroprotection and immunomodulation with mesenchymal stem cells in chronic experimental autoimmune encephalomyelitis. Arch Neurol 65: 753761.

186. Uccelli A, Laroni A, Freedman MS (2011) Mesenchymal stem cells for the treatment of multiple sclerosis and other neurological diseases. Lancet Neuro 10: 649-656.

187. Slavin S, Kurkalli BG, Karussis D (2008) The potential use of adult stem cells for the treatment of multiple sclerosis and other neurodegenerative disorders. Clin Neurol Neurosurg 110: 943-946. 
188. Siatskas C, Payne NL, Short MA, Bernard CC (2010) A consensus statement addressing mesenchymal stem cell transplantation for multiple sclerosis: it's time! Stem Cell Rev 6: 500-506.

189. Holloman JP, Ho CC, Hukki A, Huntley JL, Gallicano GI (2013) The development of hematopoietic and mesenchymal stem cell transplantation as an effective treatment for multiple sclerosis. Am J Stem Cells 2: 95-107.

190. Fraser JK, Wulur I, Alfonso Z, Hedrick MH (2006) Fat tissue: an underappreciated source of stem cells for biotechnology. Trends Biotechnol 24: $150-154$.

191. Yamout B, Hourani R, Salti H, Barada W, El-Haij T, et al. (2010) Bone marrow mesenchymal stem cell transplantation in patients with multiple sclerosis: a pilot study. J Neuroimmunol 227: 185-189.

192. Barhum Y, Gai-Castro S, Bahat-Stromza M, Brazilay R, Melamed E et al (2010). Intracerebroventricular transplantation of human mesenchymal stem cells induced to secrete neurotrophic factors attenuates clinical symptoms in a mouse model of multiple sclerosis. Journal of Molecular Neuroscience 41 129-137.

193. Connick P, Kolappan M, Crawley C, Webber DJ, Patani R, et al. (2012) Autologous mesenchymal stem cells for the treatment of secondary progressive multiple sclerosis: an open-label phase 2a proof-of-concept study. Lancet Neurol 11: 150-156.

194. Mehandru N, Cohen J (2013). A potential cure for multiple sclerosis: the promising role mesenchymal stem cells play in the reparative process. Royal College of Surgeons in Ireland Student Medical Journal 6: 54-8.

195. Silvia V. Lourencxo, Fabio R. G. de Carvalho, Paula Boggio, Mirian N Sotto, Maria A. C. Vilela, et al (2007). Lupus erythematosus: Clinical and histopathological study of oral manifestations and immunohistochemical profile of the inflammatory infiltrate. J Cutan Pathol 34: 558-564.

196. Mok CC, Lau CS (2003) Pathogenesis of systemic lupus erythematosus. J Clin Pathol 56: 481-490.

197. Schur PH (1995) Genetics of systemic lupus erythematosus. Lupus 4: 425437.

198. Pisetsky DS (1997). Systemic lupus erythematosus. A. Epidemiology, pathology and pathogenesis. In: Klippel $\mathrm{JH}$, ed. Primer on the rheumatic diseases, 11th ed. Georgia, USA: Arthritis Foundation, 246-51.

199. Bhattacharya A, Soni S, jain R, Tiwari P (2011). Systemic Lupus Erythematosus: A Review. Pharmacologyonline 3: 812-825.

200. Traggiai E, Volpi S, Schena F, Gattorno M, Ferlito F, et al. (2008) Bone marrow-derived mesenchymal stem cells induce both polyclonal expansion and differentiation of $B$ cells isolated from healthy donors and systemic lupus erythematosus patients. Stem Cells 26: 562-569.

201. Schena F, Gambini C, Gregorio A, Mosconi M, Reverberi D, et al. (2010) Interferon- $\hat{-}^{3}$-dependent inhibition of $\mathrm{B}$ cell activation by bone marrow-derived mesenchymal stem cells in a murine model of systemic lupus erythematosus. Arthritis Rheum 62: 2776-2786.

202. Sun L, Akiyama K, Zhang H, Yamaza T, Hou Y, et al. (2009) Mesenchymal stem cell transplantation reverses multiorgan dysfunction in systemic lupus erythematosus mice and humans. Stem Cells 27: 1421-1432.

203. Liang J, Zhang H, Hua B, Wang H, Lu L, et al. (2010) Allogenic mesenchymal stem cells transplantation in refractory systemic lupus erythematosus: a pilot clinical study. Ann Rheum Dis 69: 1423-1429.

204.Sun L, Wang D, Liang J, Zhang H, Feng X, et al. (2010) Umbilical cord mesenchymal stem cell transplantation in severe and refractory systemic lupus erythematosus. Arthritis Rheum 62: 2467-2475.

205. Carrion F, Nova E, Ruiz C, Diaz F, Inostroza C, et al. (2010) Autologous mesenchymal stem cell treatment increased $T$ regulatory cells with no effect on disease activity in two systemic lupus erythematosus patients. Lupus 19 317-322.

206. Choi EW, Shin IS, Park SY, Park JH, Kim JS, et al. (2012). Reversal of serologic, immunologic, and histologic dysfunction in mice with systemic lupus erythematosus by long-term serial adipose tissue-derived mesenchymal stem cell transplantation. Arthritis \& Rheumatism 64: 243-253.

207. Carrion FA, Figueroa FE (2011) Mesenchymal stem cells for the treatment of systemic lupus erythematosus: is the cure for connective tissue diseases within connective tissue? Stem Cell Res Ther 2: 23.

208. Sui W, Hou X, Che W, Chen J, Ou M, et al. (2013) Hematopoietic and mesenchymal stem cell transplantation for severe and refractory systemic lupus erythematosus. Clin Immunol 148: 186-197.

209.Sun L (2013). Mesenchymal stem cell transplantation for systemic lupus erythematosus. Essentials of Mesenchymal Stem Cell Biology and Its Clinical Translation 253-261.

210. Dai Y, Shi F, Wang L, Wu G, Shen D (2013) iBEAT: A toolbox for infant brain magnetic resonance image processing. Neuroinformatics 11: 211-225.

211. http://www.webmd.com/digestive-disorders/tc/anal-fistulas-and-crohnsdisease-topic-overview

212.http://www.nice.org.uk/nicemedia/live/13936/61001/61001.pdf

213. García-Olmo D, García-Arranz M, Herreros D, Pascual I, Peiro C et al. (2005) A phase I clinical trial of the treatment of Crohn's fistula by adipose mesenchymal stem cell transplantation. Dis Colon Rectum 48: 1416-1423.

214. Garcia-Olmo D, Herreros D, Pascual I, Pascual JA, Del-Valle E, et al. (2009) Expanded adipose-derived stem cells for the treatment of complex perianal fistula: a phase II clinical trial. Dis Colon Rectum 52: 79-86.

215. Garcia-OImo D, Herreros D, Pascual M, Pascual I, De-La-Quintana P, et al (2009) Treatment of enterocutaneous fistula in Crohn's Disease with adiposederived stem cells: a comparison of protocols with and without cell expansion. Int J Colorectal Dis 24: 27-30.

216. Duijvestein M, Vos AC, Roelofs H, Wildenberg ME, Wendrich BB, et al. (2010) Autologous bone marrow-derived mesenchymal stromal cell treatment for refractory luminal Crohn's disease: results of a phase I study. Gut 59: 16621669.

217.Duijvestein M, Molendijk I, Roelofs H, Vos AC, Verhaar AP, et al. (2011) Mesenchymal stromal cell function is not affected by drugs used in the treatment of inflammatory bowel disease. Cytotherapy 13: 1066-1073.

218. Ciccocioppo R, Bernardo ME, Sgarella A, Maccario R, Avanzini MA, et al. (2011) Autologous bone marrow-derived mesenchymal stromal cells in the treatment of fistulising Crohn's disease. Gut 60: 788-798.

219.http://www.who.int/nmh/publications/fact_sheet_cardiovascular_en.pdf

220.Toma C, Pittenger MF, Cahill KS, Byrne BJ, Kessler PD (2002) Human mesenchymal stem cells differentiate to a cardiomyocyte phenotype in the adult murine heart. Circulation 105: 93-98.

221. Kawada H, Fujita J, Kinjo K, Matsuzaki Y, Tsuma M, et al. (2004) Nonhematopoietic mesenchymal stem cells can be mobilized and differentiate into cardiomyocytes after myocardial infarction. Blood 104: 3581-3587.

222. Li H, Yu B, Zhang Y, Pan Z, Xu W, et al. (2006) Jagged1 protein enhances the differentiation of mesenchymal stem cells into cardiomyocytes. Biochem Biophys Res Commun 341: 320-325.

223. Rangappa S, Fen C, Lee EH, Bongso A, Sim EK (2003) Transformation of adult mesenchymal stem cells isolated from the fatty tissue into cardiomyocytes. Ann Thorac Surg 75: 775-779.

224. Shim WS, Jiang S, Wong P, Tan J, Chua YL, et al. (2004) Ex vivo differentiation of human adult bone marrow stem cells into cardiomyocyte-like cells. Biochem Biophys Res Commun 324: 481-488.

225. Potdar PD, Prasannan P (2013) Differentiation of Human Dermal Mesenchyma Stem Cells into Cardiomyocytes by Treatment with 5-Azacytidine: Concept fo Regenerative Therapy in Myocardial Infarction. ISRN Stem Cells 2013:1-9.

226. Xu W, Zhang X, Qian H, Zhu W, Sun X, et al. (2004) Mesenchymal stem cells from adult human bone marrow differentiate into a cardiomyocyte phenotype in vitro. Exp Biol Med (Maywood) 229: 623-631.

227. Martin-Rendon E, Sweeney D, Lu F, Girdlestone J, Navarrete C, et al. (2008) 5-Azacytidine-treated human mesenchymal stem/progenitor cells derived from umbilical cord, cord blood and bone marrow do not generate cardiomyocytes in vitro at high frequencies. Vox Sang 95: 137-148.

228. Antonitsis $\mathrm{P}$, loannidou-Papagiannaki E, Kaidoglou A, Papakonstantinou C (2007) In vitro cardiomyogenic differentiation of adult human bone marrow mesenchymal stem cells. The role of 5 -azacytidine. Interact Cardiovasc Thorac Surg 6: 593-597.

229. Liu Y, Song J, Liu W, Wan Y, Chen X, et al. (2003) Growth and differentiation of rat bone marrow stromal cells: does 5-azacytidine trigger their cardiomyogenic differentiation? Cardiovasc Res 58: 460-468.

230. Kadivar M, Khatami S, Mortazavi Y, Shokrgozar MA, Taghikhani M, et al 
Citation: Potdar PD, Deshpande SS (2013) Mesenchymal Stem Cell Transplantation: New Avenues for Stem Cell Therapies. J Transplant Technol Res 3: 122. doi:10.4172/2161-0991.1000122

Page 16 of 16

(2006) In vitro cardiomyogenic potential of human umbilical vein-derived mesenchymal stem cells. Biochem Biophys Res Commun 340: 639-647.

231. Cheng F, Zou P, Yang H, Yu Z, Zhong Z (2003) Induced differentiation of human cord blood mesenchymal stem/progenitor cells into cardiomyocyte-like cells in vitro. J Huazhong Univ Sci Technolog Med Sci 23: 154-157.

232. Balana B, Nicoletti C, Zahanich I, Graf EM, Christ T, et al. (2006) 5-Azacytidine induces changes in electrophysiological properties of human mesenchymal stem cells. Cell Res 16: 949-960.

233. Ye NS, Chen J, Luo GA, Zhang RL, Zhao YF, et al. (2006) Proteomic profiling of rat bone marrow mesenchymal stem cells induced by 5-azacytidine. Stem Cells Dev 15: 665-676.

234. Fukuda K (2001) Development of regenerative cardiomyocytes from mesenchymal stem cells for cardiovascular tissue engineering. Artif Organs 25: 187-193.

235. Wei F, Wang T, Liu J, Du Y, Ma A (2011) The subpopulation of mesenchymal stem cells that differentiate toward cardiomyocytes is cardiac progenitor cells. Exp Cell Res 317: 2661-2670.

236.Zhao Z, Chen Z, Zhao X, Pan F, Cai M, et al. (2011) Sphingosine-1-phosphate promotes the differentiation of human umbilical cord mesenchymal stem cells into cardiomyocytes under the designated culturing conditions. J Biomed Sci 18: 37 .

237. Huang Y, Zheng L, Gong X, Jia X, Song W, et al. (2012) Effect of cyclic strain on cardiomyogenic differentiation of rat bone marrow derived mesenchymal stem cells. PLOS One 7: e34960.

238. Huang YS, Li IH, Chueh SH, Hueng DY, Tai MC, et al. (2013) Mesenchymal stem cells from rat olfactory bulbs can differentiate into cells with cardiomyocyte characteristics. J Tissue Eng Regen Med.

239. Silva GV, Litovsky S, Assad JAR, Sousa ALS, Martin BJ, et al. (2005) Perin. Mesenchymal Stem Cells Differentiate into an Endothelial Phenotype, Enhance Vascular Density, and Improve Heart Function in a Canine Chronic Ischemia Model. Circulation 111: 150-156.

240. Orlic D (2003) Adult bone marrow stem cells regenerate myocardium in ischemic heart disease. Ann N Y Acad Sci 996: 152-157.
241.Tang YL, Zhao Q, Zhang YC, Cheng L, Liu M, et al. (2004) Autologous mesenchymal stem cell transplantation induce VEGF and neovascularization in ischemic myocardium. Regul Pept 117: 3-10.

242. http://www.mayoclinic.org/news2013-rst/7521.html

243. http://www.unckidneycenter.org/patiented/Kidney\%20Transplant.pdf

244. Morigi M, Imberti B, Zoja C, Corna D, Tomasoni S, et al. (2004) Mesenchymal stem cells are renotropic, helping to repair the kidney and improve function in acute renal failure. J Am Soc Nephrol 15: 1794-1804.

245.Togel F, Hu Z, Weiss K, Isaac J, Lange C, et al. (2005) Administered mesenchymal stem cells protect against ischemic acute renal failure through differentiation-independent mechanisms. AJP Renal Physiol 28 : F31-F42.

246. Herrera MB, Bussolati B, Bruno S, Fonsato V, Romanazzi GM, et al. (2004) Mesenchymal stem cells contribute to the renal repair of acute tubular epithelial injury. Int J Mol Med 14: 1035-1041.

247. Semedo P, Wang PM, Andreucci TH, Cenedeze MA, Teixeira VP, et al. (2007) Mesenchymal stem cells ameliorate tissue damages triggered by renal ischemia and reperfusion injury. Transplant Proc 39: 421-423.

248. Kunter U, Rong S, Djuric Z, Boor P, Müller-Newen G, et al. (2006) Transplanted mesenchymal stem cells accelerate glomerular healing in experimental glomerulonephritis. J Am Soc Nephrol 17: 2202-2212.

249. Grimm PC, Nickerson P, Jeffery J, Savani RC, Gough J, et al. (2001) Neointimal and tubulointerstitial infiltration by recipient mesenchymal cells in chronic renal-allograft rejection. N Engl J Med 345: 93-97.

250. Hoogduijn MJ, Popp FC, Grohnert A, Crop MJ, van Rhijn M, et al. (2010) Advancement of mesenchymal stem cell therapy in solid organ transplantation (MISOT). Transplantation 90: 124-126.

251. Tan J, Wu W, Xu X, Liao L, Zheng F, et al. (2012) Induction therapy with autologous mesenchymal stem cells in living-related kidney transplants: a randomized controlled trial. JAMA 307: 1169-1177.

252. Crop MJ, Baan CC, Korevaar SS, ljzermans JN, Alwayn IP, et al. (2009) Donor-derived mesenchymal stem cells suppress alloreactivity of kidney transplant patients. Transplantation 87: 896-906. 